\title{
Use of Diatoms in Monitoring the Sakarya River Basin, Turkey
}

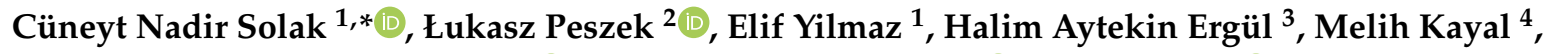 \\ Fatih Ekmekçi ${ }^{4}$, Gábor Várbíró ${ }^{5}{ }^{(0)}$, Arzu Morkoyunlu Yüce ${ }^{6}{ }^{(0}$, Oltan Canli ${ }^{7}{ }^{(0}$, \\ Mithat Sinan Binici ${ }^{7}$ and Éva Ács ${ }^{5,8}$ \\ 1 Department of Biology, Arts and Science Faculty, Dumlupınar University, 43100 Kütahya, Turkey; \\ elfyilmaz38@gmail.com \\ 2 Department of Agroecology, Institute of Agricultural Sciences, Land Management and Environmental \\ Protection, University of Rzeszów, Zelwerowicza 8B, 35-601 Rzeszów, Poland; lukaspeszek@gmail.com \\ 3 Department of Biology, Science and Literature Faculty, Kocaeli University, 41380 Kocaeli, Turkey; \\ halim.ergul@gmail.com \\ 4 Environmental Section, Investigating, Planning and Allocations Department, General Directorate of State \\ Hydraulic Works, 06100 Ankara, Turkey; melihkayal@dsi.gov.tr (M.K.); fekmekci@dsi.gov.tr (F.E.) \\ 5 MTA Centre for Ecological Research, Danube Research Institute, Karolina út 29, H-1113 Budapest, Hungary; \\ varbiro.gabor@okologia.mta.hu (G.V.); acs.eva@okologia.mta.hu (E.A.) \\ 6 Hereke O. İ. Uzunyol Vocational School, Kocaeli University, 41800 Kocaeli, Turkey; arzuyuce38@gmail.com \\ 7 TUBITAK Marmara Reserach Centre, Environment and Cleaner Production Institute, 41470 Kocaeli, Turkey; \\ oltan.canli@tubitak.gov.tr (O.C.); sinan.binici@tubitak.gov.tr (M.S.B.) \\ 8 Faculty of Water Sciences, National University of Public Service, Bajcsy-Zsilinszky utca 12-14, H-6500 Baja, \\ Hungary \\ * Correspondence: cnsolak@gmail.com
}

Received: 13 December 2019; Accepted: 21 February 2020; Published: 4 March 2020

\begin{abstract}
The Sakarya River basin is one of the largest basins in Turkey, and encompasses the Kocaeli, Düzce, Sakarya, Bursa, Bilecik, Bolu, Kütahya, Eskişehir, Ankara, Afyon, and Konya provinces. In this study, the water quality status of the basin was investigated using 18 diatom indices, calculated in Omnidia software. For this purpose, a total of 46 stations were surveyed in the rivers and streams of the basin in May 2018. As a result, 41 of 195 diatom taxa were found to be the most frequent (>10\% share in assemblage). According to Detrented Correspondence Analysis (DCA), three subgroups were described as the spring section, Ankara and Polatl section, and lowland section. The river basin quality was evaluated as moderate or lower quality status, while only a few sites had good status. The diatom index scores showed that the Descy's Index (DES), Pampean Diatom Index (IDP), Artois-Picardie Diatom Index (IDAP), and Specific Pollution Sensitivity Index (IPS) appear best suited to water quality assessment in this area, showing the largest number of significantly important correlation with environmental variables.
\end{abstract}

Keywords: diatom indices; monitoring; ecological status; Water Framework Directive

\section{Introduction}

Biological and physico-chemical monitoring have been applied in order to detect the effects of human activities on aquatic environments [1]. Water quality assessment base on physicochemical analyzes is determine the water quality only at the time of measurement. This is why, such assessment is incomplete and inaccurate because water parameters may change fast over a short time. For example, in the case of uncontrolled sewage inflow. Biological monitoring allow to analyze of this constantly changing of physical and chemical characteristics of the water, giving a real reflection of conditions in 
aquatic environment. One of first methods using living organisms in water quality assessment was Kolkwitz and Marsson saprobic system [2,3]. The use of diatoms in assessment of lotic and lentic waters, paleoenvironmental reconstructions, and climate studies was started in the 1970s $[4,5]$.

The revolutionary approach in water quality assessment was introduced by Water Framework Directive [6]. Directive assumes an integrated and coordinated approach to water management in Europe based on river basin planning and monitoring. Directive also implement the concept of "ecological status" as an expression of the quality of the structure and functioning of aquatic ecosystems associated with surface waters. In the determination of ecological status, the most important factors have become the biological and hydromorphological elements. The ecological assessment of aquatic environments is based on four group of organisms: aquatic invertebrates, fishes, macrophytes, and phytobenthos microorganisms - the diatoms. The physico-chemical water parameters becomes only supporting for the biological elements [6].

The wide diatom use in environmental studies is due to fact that they show high correlation with water parameters. The diatoms are able to quickly react to changes in the water because of short life cycle. Another advantage of them is to have narrow ecological tolerance range. They are sensitive to, for example, salinity, temperature, $\mathrm{pH}$, shading, water velocity, type of substratum, water chemistry and heavy metal contents. They can be easily collected and stored for a long time [7]. They are ideal organisms for water quality monitoring [8-11], and for this purpose diatom communities are used in routine monitoring programs. The diatom water quality indices were developed and designed in most cases base on regional data and for local environment quality assessment. In Europe [12-18] and United States $[19,20]$, diatoms are widely used in water quality assessment. Most of these indices can be calculated by using Omnidia software [21] or based on ecological data available in this software [22]. Cosmopolitan distribution of diatom taxa should give comparable results of indices, however studies showing that European indices may need to be adjusted to regional conditions [12,23]. Most of the diatom indices were created for temperate climates in the Northern Hemisphere, and often cannot be applied to tropical areas or are limited to specific conditions. Recently, warmer and tropical regions have been studied by using diatom indices [24]. Important data for biological water quality assessment are publish from Mediterranean areas [25-30], which also covering the south part of Turkey.

In Turkey, the biomonitoring program has been carried out since 2011 [31] and is still developing in order to adapt to European Union legislation, especially in relation to the Water Framework Directive. Turkish waters are especially subject to this legislation and examined accordingly. The studies of Turkish inland waters mainly concerned lakes [32], while studies of flowing waters are sparse. In the Sakarya Basin, the main rivers were investigated by different researchers. The first diatom studies in the region were conducted by Atıc1 and Y1ld1z [33,34]. A study concerning using diatoms to assess water quality was conducted by Çetin and Demir [29], mainly in the upper section of the river. A few studies concerning diatoms have also been conducted in some tributaries of the Sakarya River [32,34,35].

The Sakarya River Basin is the third-biggest river basin in Turkey, and includes highly populated cities. The present study is the first large-scale, comprehensive, scientific attempt to test the diatom indices and determine the main diatom taxa occurring in one of the most important river basins in Turkey.

\section{Methods}

\subsection{Study Area}

The Sakarya River flows through the Anatolia region (Turkey), and has a length of $824 \mathrm{~km}$. The basin covers 25 major tributary basins. The catchment area is ca. $58,160 \mathrm{~km}^{2}$, with an average altitude of $965 \mathrm{~m}$. The climate of the region is continental. The average annual precipitation is about $480 \mathrm{~mm}$ [36], with a mean temperature value of $10.5^{\circ} \mathrm{C}$ [37]. The main parent rock of this region is characterized by Triassic rock, composed mostly of conglomerates and sandstone which give way to Jurassic-Lower Cretaceous limestone and Upper Cretaceous flysch [37]. The springs of the Sakarya 
River are located in the Eskişehir-Çifteler area. The main aquifer is composed of shelf-type carbonates of the Triassic-Upper Cretaceous periods. Dolomite limestone is dominant in the lower section, while the upper section of the unit is mostly chert limestone [38].

The Sakarya River catchment area is very important in terms of the economy, agriculture, and ecology of the country, because two highly populated cities are located in the area (the capital Ankara and Sakarya). Land use of the study area is 52.6\% agricultural, forest and semi-natural areas cover $44.2 \%$, artificial uses account for $2.5 \%$, and $0.7 \%$ is occupied by waters and wetlands. Twenty-two percent of the agricultural areas can be irrigated, and this is an important factor for the availability and quality of surface waters [36].

A total of 46 stations were surveyed in the rivers and streams of the basin during May 2018 (Figure 1, Table S1).

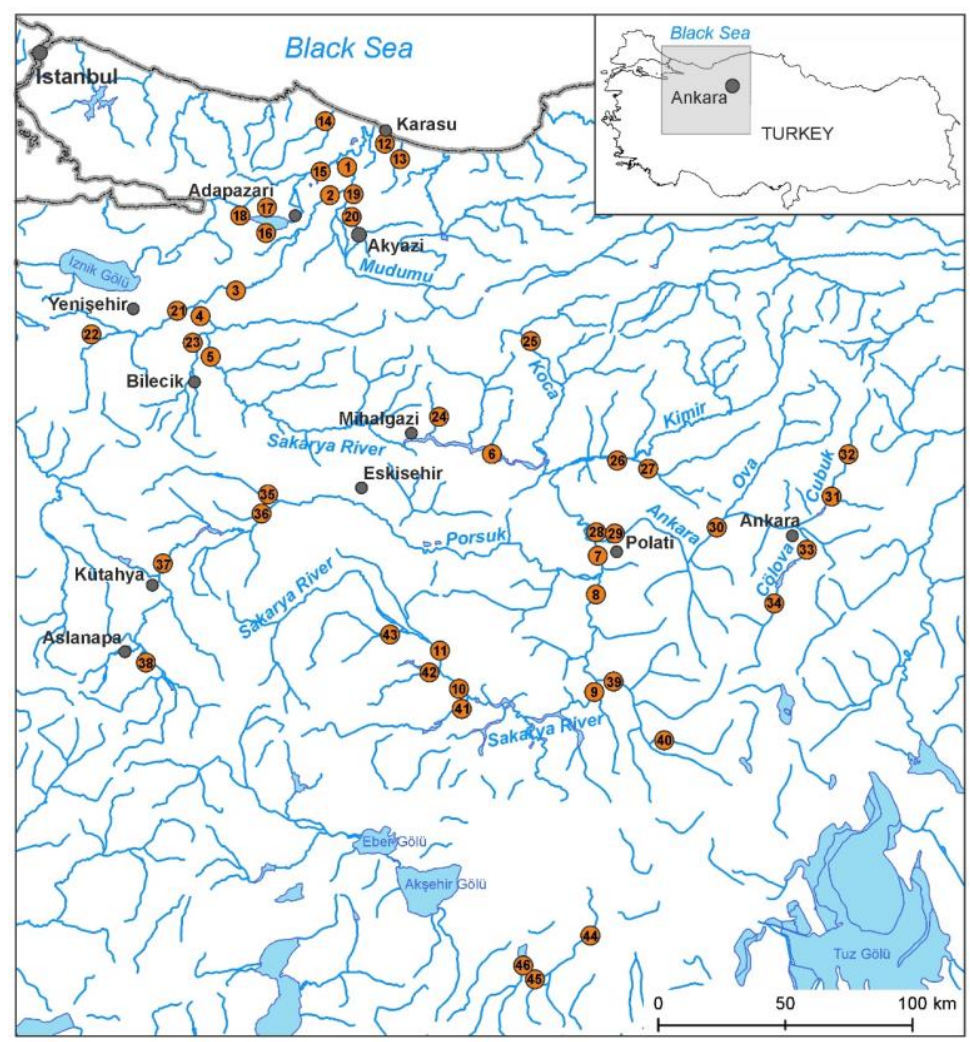

Figure 1. Location of the sampling stations (1-46) in the Sakarya River basin.

\subsection{Field and Laboratory Studies}

Sampling was conducted according to a standard method used in these types of studies [17,22]. The diatoms were collected by brushing submerged stones with hard brush. Samples were collected from 46 sampling stations during May 2018. In the laboratory, samples were boiled with $30 \% \mathrm{H}_{2} \mathrm{O}_{2}$ and $\mathrm{HCl}$ to remove organic matter. To obtain clean diatom valves, samples were washed with distilled water in centrifuge (2500 RMP). In the next step the material was air-dried on cover glasses and mounted in Naphrax ${ }^{\circledR}$ (Brunel Microscopes Ltd, Chippenham, United Kingdom) resin. Light microscope (LM) observations were conducted using an OLYMPUS BX-51 (Mitsubishi UFJ Financial Group, Tokyo, Japan). Diatoms were identified according to literature published elsewhere [39-52].

At least 400 valves in each slide were counted for all samples. Species with a content above $10 \%$ of all counted valves in diatom assemblage were defined as the most abundant. Diatom indices were calculated using OMNIDIA 4.2 (Michel Coste, Bordeaux, France) software [21]. Due to the small number of data concerning diatoms used in water quality assessment of Turkish rivers, all available diatom indices were calculated for test their applicability (Table 1). In indices calculation, the centric 
diatoms (as mainly planktonic taxa) were excluded [22]. In the present study, class limit values recommended by Elorenta and Soinien [53] and Dumnicka et al. [54] were used for the interpretation of the scores yielded by the indices. All the indices were transformed in Omnidia software to range from 0 (or 1) to 20 to be comparable (Table 2). Additionally, the Trophic Index of Turkey (TIT) was calculated for checking its applicability for assessment water quality of studied waters [55].

Table 1. List of diatom indices calculated for present work.

\begin{tabular}{ccc}
\hline Index & Reference & Stressor Type Sensibility \\
\hline Artois-Picardie Diatom Index (IDAP) & {$[56]$} & General pollution \\
Eutrophication/Pollution Index (EPI-D) & {$[15]$} & Pollution/trophc status \\
Biological Diatom Index (IBD) & {$[57]$} & General pollution \\
Steinberg and Schiefele's Index (SHE) & {$[58,59]$} & Pollution/trophic status \\
Swiss Diatom Index (DI-CH) & {$[60]$} & Trophic status \\
Specific Pollution Sensitivity Index (IPS) & {$[61]$} & General pollution \\
Sládeček's Index (SLA) & {$[62]$} & Saprobity (BOD) \\
Descy's Index (DES) & {$[63]$} & General pollution \\
Louis-Leclercq Diatomic Index (IDSE) & {$[64]$} & Saprobity \\
Generic Diatom Index (IDG) & {$[65]$} & General pollution \\
Commission for Economical Community & {$[66]$} & General pollution \\
Metric-European Index (CEE) & {$[67]$} & Eutrophication \\
Trophic-Saprobic index (LOBO) & {$[16]$} & Trophic status \\
Trophic Diatom Index (TDI) & {$[16]$} & Trophic status (Eutrophication) \\
Proportion of taxa tolerant to organic & {$[68]$} & Saprobic status \\
pollution \% PT & {$[69]$} & Trophic status \\
Rott's Saprobic Metric (ROTTs) & {$[70]$} & Saprobity (BOD) \\
Rott's Trophc Metric (ROTTt) & {$[71]$} & Organic pollution/eutrophication \\
Watanabe Index (WAT) & &
\end{tabular}

Table 2. Class limit values for diatom indices according to [53,54].

\begin{tabular}{ccc}
\hline Index Score & Ecological Status & Trophy \\
\hline$>17$ & high & oligotrophy \\
$15-17$ & good & oligo-mesotrophy \\
$12-15$ & moderate & mesotrophy \\
$9-12$ & poor & meso-eutrophy \\
$<9$ & bad & eutrophy \\
\hline
\end{tabular}

Water temperature, dissolved oxygen (DO), $\mathrm{pH}$ and electrical conductivity (EC) were measured in situ using portable equipment (Lange Hach 40d). For detailed chemical analysis, the water samples were taken from the main flow of the watercourses. The samples were stored in iceboxes and transferred to the laboratory for analysis. Total nitrogen (TN), ammonium nitrogen $\left(\mathrm{NH}_{4}{ }^{+}\right)$, nitrite $\left(\mathrm{NO}_{2}{ }^{-}\right)$, nitrate $\left(\mathrm{NO}_{3}{ }^{-}\right)$, total phosphorus (TP), and orthophosphate $\left(\mathrm{PO}_{4}{ }^{3-}\right)$ were determined according to APHA [72].

In order to verify which index had the strongest correlation with environmental variables, the Pearson correlation was performed by Statistica 13.3. Statistically significant data were considered for $p$-value $<0.05$ and $<0.01$.

To determine the diatom assemblages' similarity, the Detrented Correspondence Analysis (DCA) was made (gradient length: 4.1) with downweight rare species option. The eigenvalues were 0.389, $0.228,0.149$ and 0.117 respectively for each axes.

The Canonical Correspondence Analysis (CCA) was applied to analyze the influence of environmental factors on diatom assemblages. The gradient length for the CCA was 6.4 SD. Significant test performed for CCA analysis did not show statistical importance $(p=0.122)$.

Both analyses (DCA and CCA) were performed using Canoco 5 software. 


\section{Results}

\subsection{Physico-Chemical Water Parameters}

The water chemistry was highly changeable, depending on the part of the drainage area. Water temperature ranged between 12.7 and $23^{\circ} \mathrm{C}$, and $\mathrm{pH}$ was alkaline at each station (7.2-8.4).

Electrolytic conductivity was highly variable, from $189 \mu \mathrm{S} \cdot \mathrm{cm}^{-1}$ (station 13) to $5910 \mu \mathrm{S} \cdot \mathrm{cm}^{-1}$ (station 7). The lowest values were noted mainly in the upper sections of Sakarya River tributaries. The highest values of conductivity and nutrient levels (nitrate and phosphate ions, total nitrogen, and total phosphate) and total organic carbon content were noted at stations located in the Ankara and Polatl areas. The content of total nitrogen and forms of phosphorus were especially high at station 33 located near the capital city, Ankara, and at station 29 near Polatlı in district of Ankara. In these locations (i.e., stations $28,29,33)$ the levels of ammonium content were also very high $\left(4.03-12.0 \mathrm{mg} \cdot \mathrm{L}^{-1}\right)$. At other sampling sites, the phosphate content was generally low $\left(0.02-0.92 \mathrm{mg} \cdot \mathrm{L}^{-1}\right)$. In general, the lowest values of nutrients, especially in terms of total nitrogen content, was noted at stations located in the upper sections of the Sakarya River (stations 10,11,43) and its tributaries (i.e., at Porsuk River-stations 37, 38). The biochemical oxygen demand was extremely changeable, from 1 to $80 \mathrm{mg}$ $\mathrm{O}_{2} \cdot \mathrm{L}^{-1}$. The highest $\mathrm{BOD}_{5}$ levels were noted in the same stations at Polatli and Ankara, while the lowest in the small tributaries of the Sakarya River. The highest nutrient, total organic carbon, COD and $\mathrm{BOD}_{5}$ values were also noted at station 22, located around Yenişehir district in Ankara, and at stations 15 and 19 in the lower section of the Sakarya River basin (Table 3). 
Table 3. The physico-chemical parameters of water studied: Temp.—water temperature, EC—electrolytic conductivity, DO—dissolved oxygen, BOD—biochemical oxygen demand, COD—chemical oxygen demand, TOC — total organic carbon, TP-total phosphate.

\begin{tabular}{|c|c|c|c|c|c|c|c|c|c|c|c|c|c|}
\hline $\begin{array}{l}\text { Station } \\
\text { Number }\end{array}$ & $\underset{{ }^{\circ} \mathrm{C}}{\text { Temp. }}$ & $\mathrm{pH}$ & $\begin{array}{c}\text { EC } \\
\mu \mathrm{S} \cdot \mathrm{cm}^{-1}\end{array}$ & $\begin{array}{c}\mathrm{DO} \\
\mathrm{mg} \cdot \mathrm{L}^{-1}\end{array}$ & $\begin{array}{c}\text { BOD mg } \\
\mathrm{O}_{2} \cdot \mathrm{L}^{-1}\end{array}$ & $\begin{array}{c}\text { COD mg } \\
\mathrm{O}_{2} \cdot \mathrm{L}^{-1}\end{array}$ & $\begin{array}{c}\text { TOC } \\
\mathrm{mg} \cdot \mathrm{L}^{-1}\end{array}$ & $\begin{array}{c}\mathrm{TN} \\
\mathrm{mg} \cdot \mathrm{L}^{-1}\end{array}$ & $\begin{array}{c}\mathrm{NH}_{4}{ }^{+} \\
\mathrm{mg} \cdot \mathrm{L}^{-1}\end{array}$ & $\begin{array}{l}\mathrm{NO}_{2-} \\
\mathrm{mg} \cdot \mathrm{L}^{-1}\end{array}$ & $\begin{array}{l}\mathrm{NO}_{3-} \\
\mathrm{mg} \cdot \mathrm{L}^{-1}\end{array}$ & $\begin{array}{c}\text { TP } \\
\mathrm{mg} \cdot \mathrm{L}^{-1}\end{array}$ & $\begin{array}{l}\mathrm{PO}_{4}{ }^{3-} \\
\mathrm{mg} \cdot \mathrm{L}^{-1}\end{array}$ \\
\hline 1 & 20 & 8 & 620 & 8 & 4 & 7 & 3.93 & 2.26 & 0.078 & 0.1 & 1.43 & 0.22 & 0.238 \\
\hline 2 & 18.7 & 7.7 & 568 & 7.3 & 3 & 9.8 & 3.52 & 1.56 & 0.078 & 0.077 & 0.89 & 0.44 & 0.646 \\
\hline 3 & 17.4 & 8 & 540 & 8.8 & 1 & 14.4 & 3.99 & 1.11 & 0.06 & 0.07 & 1.41 & 0.17 & 0.308 \\
\hline 4 & 18.2 & 8.1 & 667 & 8.7 & 1 & - & - & 2.2 & 0.05 & - & 1.414 & 0.11 & - \\
\hline 5 & 18 & 8.2 & 818 & 8.5 & 2 & 12.4 & 3.96 & 2.31 & - & 0.13 & 1.56 & - & 0.693 \\
\hline 6 & 15.8 & 8.4 & 1037 & 9.2 & 4 & 15.9 & 3.61 & 8.95 & 0.731 & $<0.018$ & 5.116 & 0.607 & 1.638 \\
\hline 7 & 20.7 & 8.3 & 5910 & 11.3 & 30 & 35.3 & 2.46 & 10.71 & $<0.047$ & $<0.018$ & 8.482 & 0.467 & 1.236 \\
\hline 8 & 19.2 & 8.1 & 2059 & 6 & 9 & 11.4 & 3.09 & 10.13 & $<0.047$ & $<0.018$ & 7.972 & 3.029 & 0.892 \\
\hline 9 & 19.9 & 8.1 & 1570 & 7.6 & 4 & 6.9 & 1.76 & 2.66 & $<0.047$ & $<0.018$ & 1.723 & 0.032 & 0.057 \\
\hline 10 & 21.1 & 8.2 & 1120 & 8.6 & 1 & - & - & 0.97 & - & - & 0.59 & 0.11 & - \\
\hline 11 & 19.6 & 8.1 & 910 & 8.1 & 1 & 5.7 & 2.63 & 0.79 & - & 0.08 & 0.505 & 0.21 & 0.401 \\
\hline 12 & 22.3 & 8.2 & 1637 & 13.8 & 3 & - & - & 0.57 & - & - & 0.212 & 0.05 & - \\
\hline 13 & 16.9 & 8.1 & 189 & 9.8 & 1 & - & - & 2.17 & - & - & 0.73 & 0.04 & - \\
\hline 14 & 20.1 & 8 & 571 & 8.1 & 1 & 9.1 & - & 4.01 & 0.1 & - & 2.01 & 0.18 & 0.39 \\
\hline $\begin{array}{l}19 \\
15\end{array}$ & 17.5 & 7.6 & 693 & 4.1 & 9 & 23 & 8.71 & 6.07 & 2.71 & 0.48 & 1.079 & 1.66 & 1.258 \\
\hline 16 & 16.5 & 8 & 722 & 9.9 & 3 & 3.8 & 2.27 & 0.44 & - & - & - & - & - \\
\hline 17 & 19.2 & 8.1 & 416 & 8.9 & 2 & 3.2 & 1.68 & 0.78 & - & - & 0.54 & 0.24 & 0.05 \\
\hline 18 & 16.9 & 7.2 & 311 & 4.2 & 5 & 16.1 & 7.39 & 1.24 & 0.271 & 0.159 & 0.457 & 0.358 & $<0.260$ \\
\hline 19 & 16.6 & 8.1 & 376 & 9 & 2 & - & - & 7.98 & 0.046 & - & 1.45 & 0.06 & - \\
\hline 20 & 17.6 & 7.9 & 372 & 8.5 & 2 & - & - & 1.87 & 0.09 & - & 1.49 & 0.05 & - \\
\hline 21 & 16.4 & 8.2 & 346 & 10.2 & 3 & 17.8 & 4.81 & 2.48 & 0.008 & 0.09 & 1.07 & - & 0.281 \\
\hline 22 & 16.3 & 7.7 & 593 & 3.8 & 9 & 23.6 & 9.86 & 3.34 & 0.661 & 1.128 & 8.243 & 0.827 & 0.863 \\
\hline 23 & 16.2 & 8.2 & 405 & 8.7 & 4 & 18.8 & 6.39 & $\begin{array}{l}0.74 \\
3.74\end{array}$ & 0.778 & 0.22 & 1.46 & - & 0.36 \\
\hline 24 & 17.2 & 8.5 & 510 & 8.9 & 1 & $<5.00$ & 1.52 & 1.29 & $<0.047$ & $<0.018$ & 0.895 & 0.019 & 0.02 \\
\hline 25 & 13.9 & 7.5 & 300 & 9.6 & 4 & 4.9 & 3.34 & 1.1 & $<0.047$ & $<0.018$ & 0.635 & 0.051 & 0.095 \\
\hline 26 & 17.2 & 8.5 & 387 & 10.8 & 9 & 10.5 & 4.22 & 1.56 & 0.227 & 0.021 & 1.281 & 0.103 & 0.266 \\
\hline 27 & 17 & 7.9 & 2790 & 9.7 & 1 & - & - & 10.81 & - & - & 9.816 & 0.091 & 0.186 \\
\hline 28 & 23 & 7.7 & 1294 & 4.1 & 31 & - & - & 13.24 & 15.14 & - & - & 1.97 & - \\
\hline 29 & 21.8 & 7.8 & 1426 & 2.2 & 70 & 106.9 & 8.11 & 19.95 & 11.96 & $<0.018$ & 1.833 & 2.056 & 5.703 \\
\hline 30 & 19.9 & 7.8 & 1379 & 0.6 & 80 & 118.7 & 7.2 & 8.9 & 5.01 & $<0.018$ & 2.287 & 0.742 & 1.928 \\
\hline 31 & 17.2 & 8.2 & 503 & 7.6 & 1 & 9.2 & 3.07 & 3.36 & - & - & 3.07 & 0.58 & 0.923 \\
\hline
\end{tabular}


Table 3. Cont.

\begin{tabular}{|c|c|c|c|c|c|c|c|c|c|c|c|c|c|}
\hline $\begin{array}{l}\text { Station } \\
\text { Number }\end{array}$ & $\underset{{ }^{\circ} \mathrm{C}}{\text { Temp. }}$ & $\mathrm{pH}$ & $\begin{array}{c}\text { EC } \\
\mu \mathrm{S} \cdot \mathrm{cm}^{-1}\end{array}$ & $\begin{array}{c}\text { DO } \\
\mathrm{mg} \cdot \mathrm{L}^{-1}\end{array}$ & $\begin{array}{c}\text { BOD mg } \\
\mathrm{O}_{2} \cdot \mathrm{L}^{-1}\end{array}$ & $\begin{array}{c}\text { COD mg } \\
\mathrm{O}_{2} \cdot \mathrm{L}^{-1}\end{array}$ & $\begin{array}{c}\text { TOC } \\
\mathrm{mg} \cdot \mathrm{L}^{-1}\end{array}$ & $\begin{array}{c}\mathrm{TN} \\
\mathrm{mg} \cdot \mathrm{L}^{-1}\end{array}$ & $\begin{array}{c}\mathrm{NH}_{4}{ }^{+} \\
\mathrm{mg} \cdot \mathrm{L}^{-1}\end{array}$ & $\begin{array}{l}\mathrm{NO}_{2-} \\
\mathrm{mg} \cdot \mathrm{L}^{-1}\end{array}$ & $\begin{array}{l}\mathrm{NO}_{3-} \\
\mathrm{mg} \cdot \mathrm{L}^{-1}\end{array}$ & $\begin{array}{c}\text { TP } \\
\mathrm{mg} \cdot \mathrm{L}^{-1}\end{array}$ & $\begin{array}{l}\mathrm{PO}_{4}{ }^{3-} \\
\mathrm{mg} \cdot \mathrm{L}^{-1}\end{array}$ \\
\hline 32 & 17.5 & 7.9 & 907 & 11.2 & 4 & - & - & 2.48 & - & - & 0.871 & 0.142 & 0.345 \\
\hline 33 & 18.9 & 7.6 & 1269 & 2.3 & - & - & - & 30.31 & 4.028 & - & 1.275 & 1.176 & 3.195 \\
\hline 34 & 19.8 & 7.9 & 1021 & 6.2 & $<1$ & 18 & 5.66 & 3.29 & $<0.047$ & $<0.018$ & 1.273 & 0.034 & 0.069 \\
\hline 35 & 16 & 7.9 & 466 & 7.3 & 2 & 15.4 & 6.36 & 1.596 & 0.33 & 0.086 & 0.79 & 0.36 & 0.495 \\
\hline 36 & 12.7 & 8.1 & 481 & 9.1 & 5 & 11.4 & 4.01 & 1.52 & - & 0.025 & 1.034 & 0.11 & 0.181 \\
\hline 37 & 17.4 & 7.7 & 592 & 3.5 & 3 & 20.4 & 4.77 & 1.22 & 0.12 & 0.28 & 0.045 & 0.22 & 0.108 \\
\hline 38 & 18 & 8.4 & 489 & 12.1 & 4 & 11 & 3.41 & 0.35 & - & 0.037 & 0.17 & 0.07 & 0.107 \\
\hline 39 & 18.9 & 8 & 1633 & 8.9 & 4 & 6.4 & 1.42 & 2.84 & $<0.047$ & $<0.018$ & 2.181 & 0.029 & 0.045 \\
\hline 40 & 23 & 8.4 & 1297 & 10.6 & 7 & - & - & 6.5 & 0.741 & - & 5.579 & 0.076 & 0.146 \\
\hline 41 & 17.3 & 8 & 1182 & 7.7 & 1 & - & - & 2.29 & - & - & 1.82 & 0.54 & - \\
\hline 42 & 21.7 & 8.2 & 1065 & 8.9 & 1 & 5.8 & 3.06 & 1.42 & - & 0.06 & 1.03 & 0.33 & 0.14 \\
\hline 43 & 17 & 7.5 & 802 & 3.6 & 1 & 6.5 & 1.42 & 0.68 & - & 0.06 & 0.276 & 0.16 & 0.355 \\
\hline 44 & - & - & - & - & - & - & - & - & - & - & - & - & - \\
\hline 45 & 17.5 & 8.1 & 413 & 7.5 & 4 & 19.9 & 4.63 & 1.25 & $<0.100$ & $<0.100$ & 4.702 & 0.22 & - \\
\hline 46 & 19.2 & 8.4 & 362 & 7.2 & 4 & - & - & 0.28 & - & - & - & 0.074 & - \\
\hline
\end{tabular}




\subsection{Diatom Composition}

A total of 195 diatom taxa belonging to 67 genera were identified at the sampling stations of the Sakarya Basin (Table 4). Excluding centric diatoms (Cyclotella meneghiniana Kützing and Stephanodiscus neoastraea Håkansson and Hickel), which are not taken into consideration for diatom indices calculation, 41 diatom taxa were considered as the most abundant.

Table 4. Diatom taxa recorded during studies.

\begin{tabular}{|c|c|c|}
\hline Achnanthidium pyrenaicum & F. pygmaea & Neidiomorpha binodiformis \\
\hline Adlafia minuscula & Fistulifera saprophila & Nitzschia acicularis \\
\hline A. minuscula var. muralis & Fragilaria famelica & N. amphibia \\
\hline Amphipleura pellucida & F. tenera & N. archibaldii \\
\hline Amphora copulata & Frustulia vulgaris & N. capitellata \\
\hline A. inariensis & Geissleria decussis & N. clausii \\
\hline A. ovalis & Gomphonema calcifugum & N. communis \\
\hline A. pediculus & G. exillissimum & N. dissipata \\
\hline Aneumastus minor & G. italicum & N. dubia \\
\hline Anomoeoneis sphaerophora & G. minutum & N. filiformis \\
\hline Asterionella formosa & G. olivaceum & N. fonticola \\
\hline Aulacoseira ambigua & G. parvulum & N. frustulum \\
\hline A. granulata var. angustissima & G. subclavatum & N. hantzschiana \\
\hline Bacillaria paxillifera & Gi tergestinum & N. heufleriana \\
\hline Brachysira procera & G. truncatum & N. inconspicua \\
\hline Caloneis amphisbaena & Gyrosigma attenuatum & N. intermedia \\
\hline C. lancettula & G. kuetzingii & $N$. linearis \\
\hline C. silicula & G. obtusatum & N. media \\
\hline Cocconeis pediculus & G. sciotense & N. microcephala \\
\hline C. placentula & Halamphora montana & N. palea \\
\hline C. placentula var. lineata & H. veneta & N. pusilla \\
\hline C. pseudolineata & Hantzschia amphioxys & N. radicula \\
\hline Conticribra weissflogii & Hippodonta capitata & N. recta \\
\hline Craticula accomoda & Humidophila contenta & N. sociabilis \\
\hline C. ambigua & Karayevia clevei & N. solita \\
\hline C. buderi & K. pleonensis & N. subtilis \\
\hline C. molesta & Lemnicola hungarica & N. thermaloides \\
\hline C. subminuscula & Lindavia balatonis & N. umbonata \\
\hline Ctenophora pulchella & Luticola mutica & N. wuellerstroffii \\
\hline Cyclostephanos dubius & L. nivalis & Pantocsekiella ocellata \\
\hline C. invisitatus & L. ventricosa & Pinnularia brebissonii \\
\hline Cyclotella atomus & L. similis & Planothidium lanceolatum \\
\hline C. cryptica & Mayamaea atomus & Pseudostaurosira brevistriata \\
\hline C. meneghiniana & Melosira varians & Reimeria sinuata \\
\hline Cymatopleura solea & Meridion circulare & R. uniseriata \\
\hline C. solea var. apiculata & Navicula antonii & Rhoicosphenia abbreviata \\
\hline Cymbella compacta & N. capitatoradiata & Rhopalodia gibba \\
\hline C. excisa & N. cari & Sellaphora pupula \\
\hline C. neocistula & N. caterva & S. radiosa \\
\hline C. neolanceolata & N. cincta & S. seminulum \\
\hline C. tumida & N. cryptocephala & S. saugerressii \\
\hline Cymbopleura amphicephala & N. cryptofallax & Stauroneis separanda \\
\hline C. vrana & N. cryptotenella & S. smithii \\
\hline Denticula kutzingii & N. cryptotenelloides & Staurophora tackei \\
\hline Diadesmis confervaceae & N. erifuga & Staurosira construens \\
\hline Diatoma ehrenbergii & N. germainii & Stephanodiscus hantzschii \\
\hline D. mesodon & N. gottlandica & S. minutulus \\
\hline D. moniliformis & N. gregaria & S. neoastreae \\
\hline D. tenuis & N. kotschyi & Surirella angusta \\
\hline D. vulgaris & N. lacuum & S. brebissonii \\
\hline
\end{tabular}


Table 4. Cont.

\begin{tabular}{ccc}
\hline Diploneis oculata & N. lanceolata & S. gracilis \\
D. separanda & N. novaesiberica & S. minuta \\
Discostella stelligera & N. oblonga & S. neglecta \\
Ellerbeckia arenaria & N. phylleptosoma & S. ovalis \\
Encyonema caespitosum & N. radiosa & Tabularia fasciculata \\
E. lacustre & N. reichardtiana & Tryblionella angustata \\
E. minutum & N. rostellata & T. angustatula \\
E. silesiacum & N. salinarum & T. apiculata \\
E. ventricosum & N. simulata & T. brunoi \\
Encyonopsis minuta & N. tripunctata & T. calida \\
E. subminuta & N. trivialis & T. debilis \\
Entomoneis paludosa var. subsalina & N. upsaliensis & T. hungarica \\
Epithemia adnata & N. vandamii & Ulnaria acus \\
E. sorex & N. vilaplanii & U. biceps \\
Fallacia lenzii & N. veneta & U. nanana \\
\hline
\end{tabular}

The most common taxa in the basin are listed in Figure 2. The most frequent taxa in the Sakarya River were Amphora pediculus (Kützing) Grunow, Cymbella excisa Krammer, Cyclotella meneghiniana Kützing, and Stephanodiscus neoastraea (Kützing) Grunow, while Navicula lanceolata Ehrenberg, Nitzschia dissipata (Kützing) Rabenhorst, and Stephanodiscus neoastraea (Kützing) Grunow were dominant in the Porsuk River-another important river and one of the main branches of the Sakarya River. Other important rivers in the basin are the Ankara and Çubuk Rivers. Craticula accomoda (Hustedt) D.G.Mann, Craticula subminuscula (Manguin) C.E.Wetzel and Ector and Fistulifera saprophila (Lange-Bertalot and Bonik) Lange-Bertalot were abundant taxa in these rivers.

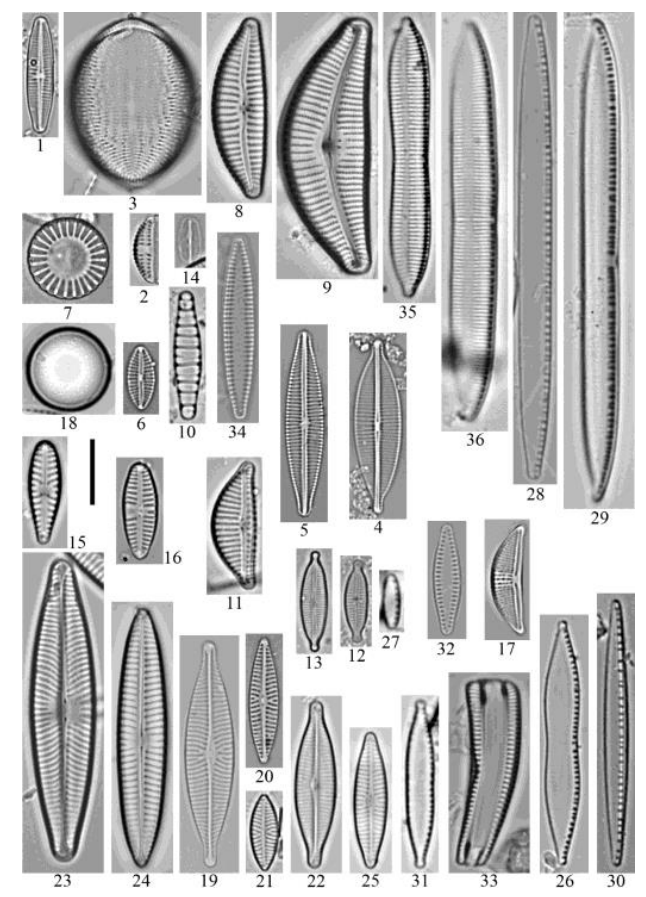

Figure 2. The most common taxa in the basin and abundant taxa in the stations. 1-Achnanthidium pyrenaicum, 2-Amphora pediculus, 3-Cocconeis pediculus, 4-Craticula accomoda, 5-Craticula buderi, 6-Craticula subminuscula, 7-Cyclotella meneghiniana, 8-Cymbella excisa, 9-C. neocistula, 10-Diatomamoniliformis, 11-Encyonema ventricosum, 12-Encyonopsis minuta, 13-E. subminuta, 14-Fistulifera saprophila, 15-Gomphonema olivaceum, 16-Gomphonema tergestinum, 17-Halamphora veneta, 18-Melosira varians, 19-Navicula capitatoradiata, 20-N. cryptotenella, 21-N. cryptotenelloides, 
22-N. gregaria, 23-N. lanceolata, 24-N. tripunctata, 25-N. veneta, 26-Nitzschia capitellata, 27-N. inconspicua, 28-Nitzschia intermedia, 29-N. linearis, 30-N. media, 31-N. palea, 32-Pseudostaurosira brevistriata, 33-Rhoicosphenia abbreviata, 34-Tabularia fasciculata, 35-Tryblionella apiculata, 36-T. hungarica. Scale bar: $10 \mu \mathrm{m}$.

For the study of the similarities in diatom assemblages, the DCA analysis was performed for all taxa identified at each site. The DCA analysis showed the differentiation of diatom assemblages mainly by location of the sampling sites in the area of the basin (Figure 3). The diatom community structure is closely reflected by a gradient of increasing pollution, from highly polluted sites to other communities. Three groups were observed as a result of the DCA analysis. The first (group A) includes diatom assemblages collected from the station located mainly in the spring section of the Sakarya River and small tributaries (Figure 3). This association was dominated by Achnanthidium pyrenaicum (Hustedt) Kobayasi, Amphora pediculus, Cymbella excisa, Gomphonema tergestinum (Grunow) Fricke, Navicula cryptotenelloides Lange-Bertalot, Pseudostaurosira brevistriata (Grunow) D.M. Williams and Round, Rhoicosphenia abbreviata (Grunow) D.M. Williams and Round and Staurosira construens Ehrenberg. The second group (group B) consisted of assemblages from areas around Ankara and Polatl (Figure 3), and was dominated by Craticula accomoda, C. buderi (Hustedt) Lange-Bertalot, C. subminuscula, Fistulifera saprophila, Navicula cryptotenella Lange-Bertalot, Nitzschia capitellata Hustedt, N. palea (Kützing) W. Smith, N.pusilla Grunow and Tryblionella hungarica (Grunow) Frenguelli. The third group (group C) consisted of assemblages mainly from the stations located in the lower section of the Sakarya River and its tributaries (Figure 3). The most frequent taxa to occur in this group were Amphora pediculus, Navicula tripunctata (O.F.Müller) Bory, N. lanceolata, N. gregaria Donkin, Nitzschia palea, N. inconspicua Grunow, and less frequently, Cocconeis placentula Ehrenberg, Fistulifera saprophila, Navicula caterva Hohn and Hellermann, N. cryptotenella, N. veneta Kützing, Nitzschia dissipata, N. intermedia Hantzsch, N. media Hantzsch, and Ulnaria nanana Lange-Bertalot. The most distinctive assemblage was found in station 34 (Figure 3). It was the only station dominated by Ctenophora pulchella (Ralfs ex Kützing) D. M. Williams and Round, Halamphora veneta (Kützing) Levkov, and Tabularia fasciculata (C. Agardh) D. M. Williams.

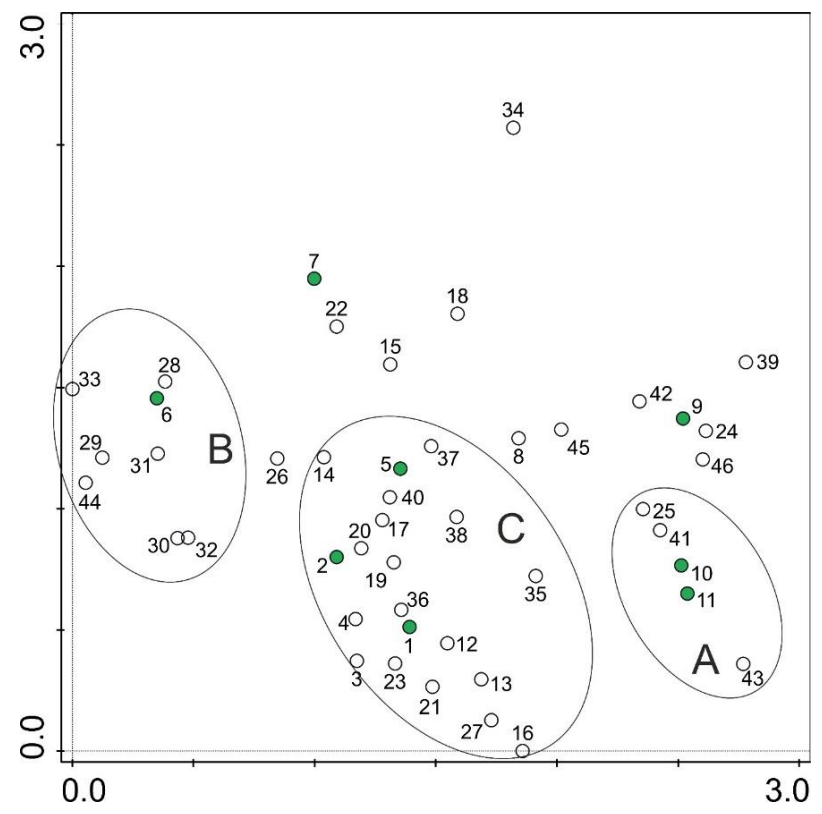

Figure 3. Results of the differentiation of diatom assemblages based on Detrented Correspondence Analysis (1-46-sampling stations, A-C - groups of diatom assemblages: A-spring section of the Sakarya River and small tributaries, B-assemblages from the area around Ankara and Polatll, C-lower section of the Sakarya River and tributaries, green dots correspond to stations located on the Sakarya River). 
To examine the influence of the environmental variables on the most abundant diatom taxa, a CCA analysis was performed. The altitude of stations was significant $(p=0.008)$ and explains $9.0 \%$ of the variability of diatom assemblages, but the significance test performed for CCA analysis did not show statistical importance $(p=0.122)$.

The diatom index scores in the sampling stations are given in Table 5. Index values were different through the stations according to the percentage of species used in the calculation of indices. The IBD, IPS, IDG, and TDI indices included the highest amount of species diversity. The IBD, IPS, and IDG indices were calculated in almost all stations with more than $90 \%$ identified taxa. The DES and LOBO indices worked in a few stations with only about $60 \%$ of our species. Regarding IBD, $7 \%$ of the stations were of "high" and "good" quality status, while 93\% were "moderate" or lower. For IPS, 19\% of the stations were "good" and $81 \%$ were "moderate" or lower. For IDG, only $8 \%$ of the stations were "high" or "good" and 92\% were "moderate" or lower ecological status.

As a result, the river basin quality was evaluated as moderate or lower quality status, while only a few sites had good status (Table 5). The Sakarya River generally had moderate or lower water quality status according to IPS and IDG indices, while a few sites were of good status regarding the IBD index. The Porsuk River have bad quality below Kütahya province. The main reason for the low water quality was related to certain regional industrial discharges, such as from ceramic factories. Based on the index results, the Ankara River has a relatively better status than the Sakarya and Porsuk Rivers. The diatom index values were highly variable along the Sakarya River. Higher values were noted in spring sections of rivers and streams (i.e., group A) (Figure 3), and in the lower section at stations 1, 3, 5, 8, and 9 located near Polatl1. At certain Sakarya River tributaries high values of indices were recorded in the spring section of the Porsuk River (station 38) and small watercourses in the north part of the basin (stations 12,13). The lowest values of diatom indices were recorded in stations located in an area of Polatlı and Ankara (i.e., group B) (Figure 3), in the Porsuk River (station 37), and also at stations 40, 44, and 45. The the highest values (the highest ecological status) were obtained by the DES $(\mathrm{mean}=13.1)$, WAT $($ mean $=11.3)$, LOBO $($ mean $=11.1)$, ROTT saprobic $($ mean $=10.7)$, SHE $($ mean $=10.5)$, and IPS $($ mean $=10.1)$ indices. The lowest ecological status was determined by the TDI index $(\operatorname{mean}=4.7)$ and ROTT trophic (mean $=5.4)$. The water typology is an integration component of the TIT (Trophc Index Turkey) formula. However, since determination of the ecoregions (water typology) of the Sakarya River Basin is not complete, the ecological status according to the TIT cannot be determined in the present study.

The correlations between all the diatom indices, including the Shannon Diversity $\left(\mathrm{H}^{\prime}\right)$ and Evenness indices, physicochemical parameters and altitude, were evaluated at $p$-values 0.05 and 0.01. The IDAP, EPI-D, IBD, SHE, DI-CH, IPS, SLA, DES, IDSE, and ROTT saprobic indices had negative significant correlations with $\mathrm{BOD}_{5}, \mathrm{COD}$, Total-N, $\mathrm{NH}_{4}{ }^{+}$, and $\mathrm{PO}_{4}{ }^{3}$ at $p$-value 0.05 (the correlation coefficient ranged between 0.45 and 0.65 ). The IBD and DES indices also had positive significant correlations with DO (i.e., $r=0.39$ and 0.44 respectively) and only the DES index had negative significant correlations with Total $\mathrm{P}(\mathrm{r}=-0.44)$ at $p=0.01$. Significant positive correlations were also determined between Dissolved Oxygen and IDAP, SHE, IPS, SLA, IDSE, and IDP indices at $p$-value 0.05 (correlation coefficients ranged between -0.31 and -0.34 ). Altitude, Temperature, TOC and Total P mostly showed negative correlations with the indices, and some were significant at $p$-value 0.05 (Table 6). Among the indices evaluated, IDP, DES, and IDAP were significantly correlated with the largest number of environmental variables (i.e., 11, 11, and 10, variables respectively). The CEE, ROTT trophic, TDI, and IDG indices had 4, 3, 1, and 1 significant correlations with the environmental variables at $p$-value 0.01 , and had $3,4,1$, and 2 significant correlations at $p$-value 0.05 , respectively. The WAT, TIT, and IDP indices had no significant correlations with the environmental variables at $p$-value 0.01 , whereas they had 6, 2 and 11 significant correlations with the same variables at $p$-value 0.05 , respectively. On the other hand, the LOBO and \% PT indices had no significant correlations with the examined variables. In general, most of diatom indices evaluated in the frame of the present study were significantly correlated with important nutrients (Table 6). 
Table 5. The diatom index values at sampling stations and corresponding ecological status (blue—high, green—good, yellow—moderate, orange—poor, red—bad).

\begin{tabular}{|c|c|c|c|c|c|c|c|c|c|c|c|c|c|c|c|c|c|c|c|c|c|}
\hline Station No. & IDAP & EPI-D & IBD & SHE & DI-CH & WAT & IPS & SLA & DES & IDSE/5 & IDG & CEE & TDI/20 & $\%$ PT & LOBO & IDP & ROTTt & ROTTs & TIT & $\mathbf{H}^{\prime}$ & Evenness \\
\hline 1 & 14.2 & 11.2 & 12.5 & 13.7 & 11.3 & 12.3 & 15.7 & 11.9 & 19.5 & 13.6 & 12.3 & 12.8 & 2.9 & 18.2 & 16.3 & 10.6 & 5.3 & 13.0 & 3.1 & 2.92 & 0.65 \\
\hline 2 & 8.7 & 7.4 & 4.5 & 9.1 & 7.2 & 10.7 & 6.7 & 9.1 & 17.2 & 9.3 & 9.1 & & 3.7 & 12.3 & 11.8 & 9.1 & 4.5 & 10.5 & 3.2 & 2.28 & 0.47 \\
\hline 3 & 12.4 & 9.7 & 10.7 & 12.7 & 9.2 & 11.8 & 14.0 & 10.8 & 18.8 & 12.8 & 10.3 & 12.2 & 2.5 & 29.3 & 16.4 & 9.6 & 4.8 & 12.3 & 3.7 & 2.82 & 0.85 \\
\hline 4 & 10.8 & 7.2 & 10.3 & 8.6 & 6.3 & 11.5 & 9.6 & 9.8 & 16.5 & 9.5 & 8.2 & 11.1 & 1.8 & 16.8 & 11.3 & 8.5 & 5.5 & 9.2 & 2.7 & 3.31 & 0.72 \\
\hline 5 & 12.9 & 8.7 & 7.9 & 2.9 & 6.8 & 12.4 & 11.5 & 8.9 & 17.0 & 9.0 & 10.2 & 9.6 & 4.7 & 14.6 & 11.6 & 10.3 & 6.5 & 13.3 & 3.0 & 3.59 & 0.75 \\
\hline 6 & 5.9 & 0.3 & 4.8 & 3.3 & 3.9 & 9.0 & 4.1 & 6.6 & 5.4 & 6.4 & 6.0 & 3.1 & 2.4 & 41.4 & 6.0 & 6.9 & 2.2 & 57 & 2.8 & 2.55 & 0.69 \\
\hline 7 & 6.4 & 6.1 & 5.9 & 4.4 & 3.3 & 6.4 & 3.8 & 7.7 & 2.0 & 6.9 & 3.2 & 3.9 & 3.1 & 60.5 & 20.0 & 2.2 & 4.0 & 6.4 & 2.8 & 2.07 & 0.74 \\
\hline 8 & 13.7 & 10.5 & 9.9 & 14.5 & 8.5 & 16.9 & 12.8 & 10.8 & 15.1 & 12.0 & 10.9 & 11.5 & 4.2 & 15.9 & 14.6 & 6.2 & 5.9 & 12.1 & 2.9 & 2.80 & 0.63 \\
\hline 9 & 14.1 & 11.8 & 10.3 & 14.9 & 9.4 & 16.3 & 14.7 & 11.1 & 15.5 & 12.0 & 12.5 & 12.2 & 6.7 & 9.4 & 19.4 & 10.5 & 6.4 & 12.6 & 2.9 & 2.99 & 0.65 \\
\hline 10 & 12.1 & 15.1 & 16.4 & 16.2 & 16.0 & 14.6 & 16.4 & 10.1 & 16.1 & 12.4 & 15.3 & 15.4 & 11.1 & 7.9 & 10.5 & 11.2 & 8.7 & 15.4 & 3.0 & 3.36 & 0.68 \\
\hline 11 & 14.2 & 14.3 & 11.9 & 15.9 & 13.6 & 12.9 & 14.3 & 11.9 & 19.2 & 13.1 & 13.4 & 13.9 & 8.1 & 5.3 & 11.8 & 10.6 & 6.7 & 15.7 & 2.7 & 2.99 & 0.59 \\
\hline 12 & 7.9 & 7.3 & 8.3 & 9.8 & 7.5 & 12.3 & 6.8 & 11.3 & 14.5 & 9.3 & 5.5 & 10.3 & 3.1 & 73.5 & 9.9 & 6.9 & 3.0 & 11.0 & 3.4 & 3.29 & 0.69 \\
\hline 13 & 13.2 & 12.2 & 13.8 & 13.3 & 13.0 & 16.7 & 15.6 & 11.8 & 18.7 & 12.8 & 10.8 & 14.7 & 4.9 & 17.5 & 12.1 & 10.2 & 6.6 & 13.3 & 3.6 & 2.90 & 0.65 \\
\hline 14 & 11.7 & 11.5 & 18.4 & 9.1 & 7.4 & 17.4 & 13.6 & 11.5 & 17.0 & 10.2 & 12.1 & 11.8 & 8.8 & 5.8 & 2.1 & 10.3 & 7.9 & 10.8 & 3.5 & 2.02 & 0.44 \\
\hline 15 & 10.1 & 8.6 & 10.6 & 11.5 & 7.9 & 11.9 & 10.3 & 9.4 & 13.6 & 10.1 & 10.5 & 9.4 & 4.8 & 41.7 & 12.4 & 8.6 & 3.9 & 10.9 & 2.8 & 4.40 & 0.83 \\
\hline 16 & 13.1 & 14.2 & 15.4 & 14.2 & 13.9 & 17.8 & 16.6 & 13.2 & 18.2 & 13.6 & 10.9 & 13.9 & 6.0 & 10.7 & 18.9 & 13.9 & 8.4 & 14.0 & 3.9 & 2.39 & 0.54 \\
\hline 17 & 10.3 & 7.1 & 8.4 & 8.7 & 5.0 & 8.1 & 5.9 & 8.8 & 8.4 & 8.2 & 6.4 & 4.8 & 2.8 & 50.8 & 17.9 & 4.7 & 4.3 & 8.1 & 3.0 & 3.23 & 0.65 \\
\hline 18 & 9.5 & 7.0 & 8.8 & 11.4 & 8.5 & 13.6 & 10.0 & 9.7 & 15.9 & 10.5 & 11.5 & 11.6 & 7.2 & 10.1 & 6.3 & 9.1 & 5.0 & 11.1 & 2.7 & 3.42 & 0.68 \\
\hline 19 & 13.3 & 10.0 & 11.5 & 11.9 & 9.4 & 14.1 & 13.1 & 11.3 & 18.9 & 11.2 & 10.2 & 12.2 & 2.6 & 25.1 & 9.4 & 9.8 & 6.1 & 12.1 & 2.9 & 3.78 & 0.75 \\
\hline 20 & 11.5 & 8.1 & 11.9 & 9.8 & 8.1 & 13.0 & 11.2 & 9.2 & 16.8 & 10.5 & 10.8 & 10.9 & 3.2 & 26.0 & 10.5 & 9.2 & 4.9 & 10.5 & 2.5 & 3.99 & 0.83 \\
\hline 21 & 13.1 & 10.8 & 10.8 & 12.8 & 9.1 & 12.9 & 14.9 & 13.0 & 18.5 & 13.1 & 8.4 & 13.5 & 2.8 & 25.7 & 13.7 & 10.8 & 5.7 & 12.5 & 3.6 & 2.66 & 0.68 \\
\hline 22 & 10.1 & 8.5 & 10.1 & 8.5 & 5.3 & 14.5 & 10.3 & 9.5 & 12.2 & 9.8 & 12.8 & 9.4 & 2.5 & 47.7 & 10.2 & 5.7 & 4.4 & 9.4 & 2.8 & 3.12 & 0.68 \\
\hline 23 & 12.4 & 10.5 & 9.5 & 12.4 & 7.8 & 17.1 & 12.6 & 12.3 & 18.9 & 12.8 & 7.2 & 11.8 & 0.9 & 20.4 & 1.8 & & 6.1 & 11.8 & 3.9 & 1.38 & 0.36 \\
\hline 24 & 14.3 & 14.9 & 14.0 & 18.8 & 16.7 & 10.7 & 15.6 & 10.2 & 16.7 & 12.0 & 16.9 & 11.6 & 8.0 & 0.2 & 2.1 & 13.0 & 10.8 & 13.7 & 3.1 & 2.36 & 0.62 \\
\hline 25 & 15.0 & 14.1 & 11.7 & 19.3 & 15.7 & 11.5 & 15.4 & 9.8 & 18.1 & 14.2 & 13.9 & 14.3 & 8.5 & 0.3 & 11.3 & 8.1 & 12.6 & 14.1 & 3.0 & 1.67 & 0.44 \\
\hline 26 & & & 2.6 & 2.5 & 3.5 & 9.4 & 2.1 & 7.5 & 5.7 & 4.8 & & & 4.3 & 75.1 & 19.1 & 7.8 & & & 3.9 & 1.59 & 0.42 \\
\hline 27 & 10.5 & 9.6 & 8.2 & 11.8 & 8.3 & 14.6 & 12.7 & 13.6 & 16.8 & 11.3 & 4.9 & 11.5 & 0.8 & 55.2 & 2.4 & 13.6 & 6.1 & 12.1 & 3.9 & 1.73 & 0.55 \\
\hline 28 & 1.9 & 1.8 & 3.7 & 1.4 & 3.2 & 6.2 & 1.2 & 7.6 & 1.2 & 5.4 & 1.8 & 3.7 & 3.4 & 90.1 & 19.6 & 2.3 & 2.4 & 3.8 & 3.1 & 1.62 & 0.45 \\
\hline 29 & 1.7 & 2.4 & 1.2 & 2.3 & 1.8 & 2.6 & 1.7 & 5.0 & 1.3 & 1.6 & 7.9 & 4.2 & 1.1 & 7.1 & 3.1 & 4.5 & 1.7 & 3.5 & 3.9 & 1.59 & 0.53 \\
\hline 30 & 2.8 & 2.9 & 2.9 & 5.1 & 2.4 & 3.2 & 2.8 & 4.6 & 1.0 & 4.2 & 8.0 & 5.6 & 0.7 & 0.5 & 15.2 & 4.6 & 1.8 & 6.2 & 3.9 & 1.40 & 0.54 \\
\hline 31 & 2.7 & 3.1 & 3.0 & 2.8 & 2.4 & 2.5 & 2.5 & 5.8 & 2.2 & 2.9 & 6.7 & 4.6 & 1.2 & 29.2 & 12.3 & 4.3 & 2.3 & 4.3 & 3.7 & 2.22 & 0.67 \\
\hline 32 & 5.9 & 4.1 & 11.1 & 2.7 & 5.0 & 2.3 & 6.0 & 6.0 & 15.4 & 6.1 & 7.5 & 9.6 & 1.1 & 0.8 & 5.4 & 9.3 & 5.7 & 3.6 & 2.3 & 1.13 & 0.36 \\
\hline 33 & 1.4 & 1.3 & 2.0 & 1.1 & 3.1 & 8.3 & 1.1 & 7.0 & 1.2 & 4.1 & 2.8 & 1.3 & 4.2 & 76.0 & 4.6 & 4.6 & 1.5 & 3.6 & 4.0 & 1.07 & 0.46 \\
\hline 34 & 5.8 & 7.7 & 6.1 & 13.8 & 12.3 & 10.6 & 7.8 & 8.6 & 10.8 & 14.9 & 7.0 & 14.5 & 2.7 & 3.5 & 1.0 & & 11.3 & 15.7 & 1.1 & 1.84 & 0.55 \\
\hline 35 & 11.3 & 10.4 & 9.0 & 14.5 & 7.9 & 15.7 & 11.4 & 12.4 & 13.2 & 11.7 & 6.4 & 11.8 & 3.6 & 19.0 & 17.5 & 9.8 & 4.0 & 12.6 & 3.3 & 3.09 & 0.74 \\
\hline 36 & 12.0 & 9.7 & 8.7 & 13.7 & 10.7 & 11.2 & 11.0 & 10.9 & 17.2 & 11.2 & 11.4 & 12.8 & 1.4 & 51.1 & 14.6 & 10.6 & 3.6 & 11.7 & 3.1 & 2.02 & 0.49 \\
\hline 37 & 6.2 & 6.1 & 6.3 & 6.3 & 5.3 & 8.2 & 5.0 & 7.8 & 6.3 & 6.6 & 6.2 & 5.8 & 3.9 & 50.0 & 19.6 & 4.2 & 3.8 & 8.3 & 3.0 & 3.76 & 0.73 \\
\hline 38 & 14.3 & 11.6 & 13.4 & 13.2 & 11.2 & 16.0 & 15.4 & 13.0 & 18.6 & 13.8 & 11.7 & 13.9 & 4.0 & 13.9 & 8.0 & 12.0 & 6.8 & 12.9 & 2.4 & 3.65 & 0.74 \\
\hline 39 & 7.6 & 14.3 & 14.4 & 18.9 & 8.6 & & 16.2 & & 17.6 & 10.2 & 17.6 & 10.7 & 16.5 & 3.6 & 13.7 & 9.6 & 7.7 & 15.4 & 2.9 & 2.82 & 0.61 \\
\hline 40 & 6.5 & & & 9.3 & 7.2 & 9.9 & 4.8 & 7.5 & 8.6 & 8.2 & 6.3 & 4.2 & 3.3 & 58.9 & 9.0 & 5.7 & 5.1 & 10.6 & 2.5 & 2.65 & 0.62 \\
\hline 41 & 12.2 & 12.4 & 9.9 & 14.5 & 12.0 & 14.5 & 14.1 & 10.7 & 16.0 & 11.5 & 11.3 & 11.5 & 4.8 & 10.3 & 15.7 & 9.8 & 6.0 & 13.3 & 2.8 & 4.09 & 0.79 \\
\hline 42 & 12.1 & 11.4 & 10.9 & 13.4 & 8.6 & 12.3 & 12.3 & 9.5 & 15.1 & 11.3 & 10.6 & 7.8 & 7.7 & 22.4 & 14.9 & 8.8 & 5.0 & 12.5 & 2.8 & 4.55 & 0.85 \\
\hline 43 & 15.8 & 13.8 & 10.0 & 14.3 & 15.0 & 10.9 & 13.3 & 14.0 & 16.3 & 13.5 & 13.4 & 14.9 & 12.6 & & 1.0 & 12.8 & 7.9 & 17.9 & 1.6 & 2.40 & 0.56 \\
\hline 44 & 3.0 & 2.8 & 4.5 & 2.6 & 3.5 & 3.5 & 2.7 & 5.6 & 1.6 & 3.7 & 7.8 & 2.9 & 1.7 & 11.9 & 1.9 & 4.4 & 2.7 & 3.6 & 3.7 & 2.47 & 0.67 \\
\hline 45 & 6.8 & 11.4 & 11.4 & 13.6 & 8.0 & 10.8 & 11.1 & 7.8 & 14.1 & 8.3 & 13.5 & 5.6 & 9.0 & 15.4 & 12.3 & 9.1 & 4.2 & 10.8 & 3.1 & 3.79 & 0.74 \\
\hline 46 & 11.4 & 13.4 & 13.0 & 15.2 & 10.4 & 10.5 & 15.1 & 8.3 & 15.3 & 12.5 & 15.2 & 8.4 & 11.7 & 3.4 & 9.2 & 13.1 & 8.2 & 14.0 & 2.8 & 3.53 & 0.73 \\
\hline
\end{tabular}


Table 6. Pearson correlations between diatom indices and physico-chemical parameters of water and sampling station altitudes $\left({ }^{*} p<0.05,{ }^{* *} p<0.01\right)$ : Temp.-Water temperature, EC—electrolytic conductivity, BOD—biochemical oxygen demand, COD—chemical oxygen demand, TOC—total organic carbon, $\mathrm{H}^{\prime} —$ Shannon Diversity index, E-Evenness index, $\mathrm{n}$-number of cases.

\begin{tabular}{|c|c|c|c|c|c|c|c|c|c|c|c|c|c|c|c|c|}
\hline Diatom Index & Altitude & Temp. & $\mathrm{pH}$ & EC & $\mathrm{O}_{2}$ & $\mathrm{BOD}_{5}$ & COD & TOC & Total N & $\mathrm{NH}_{4}{ }^{+}$ & $\mathrm{NO}_{2-}$ & $\mathrm{NO}_{3-}$ & Total P & $\mathrm{PO}_{4}{ }^{3-}$ & $\mathrm{SO}_{4}{ }^{2-}$ & $\mathrm{Cl}^{-}$ \\
\hline IDAP & $-0.32 *$ & $-0.34 *$ & 0.09 & -0.24 & $0.34 *$ & $-0.57 * *$ & $-0.60 * *$ & $-0.36^{*}$ & $-0.57 * *$ & $-0.61^{* *}$ & 0.01 & -0.18 & $-0.32 *$ & $-0.58^{* *}$ & -0.13 & -0.30 \\
\hline EPI-D & -0.07 & -0.18 & 0.08 & -0.17 & 0.28 & $-0.49^{* *}$ & $-0.53^{* *}$ & $-0.41 *$ & $-0.57^{* *}$ & $-0.55^{* *}$ & -0.04 & -0.17 & $-0.37^{*}$ & $-0.56^{* *}$ & -0.09 & -0.22 \\
\hline IBD & -0.26 & -0.15 & 0.13 & -0.26 & $0.39^{* *}$ & $-0.55^{* *}$ & $-0.56^{* *}$ & -0.35 & -0.58 ** & $-0.56^{* *}$ & 0.10 & -0.19 & $-0.40^{*}$ & $-0.59 * *$ & -0.13 & -0.25 \\
\hline SHE & -0.02 & -0.23 & 0.03 & -0.20 & 0.23 & $-0.45^{* *}$ & $-0.47^{* *}$ & -0.32 & -0.54 ** & $-0.56^{* *}$ & -0.14 & -0.17 & $-0.34^{*}$ & $-0.55^{* *}$ & -0.18 & -0.28 \\
\hline DI-CH & -0.03 & -0.25 & 0.02 & -0.26 & 0.26 & $-0.50^{* *}$ & $-0.53 * *$ & $-0.40^{*}$ & -0.52 ** & $-0.50^{* *}$ & -0.19 & -0.32 & -0.40 * & $-0.54^{* *}$ & -0.22 & -0.34 \\
\hline IPS & -0.22 & -0.30 * & 0.10 & -0.26 & 0.31 * & $-0.53^{* *}$ & $-0.55^{\text {** }}$ & -0.33 & $-0.55^{* *}$ & $-0.58^{* *}$ & -0.02 & -0.17 & $-0.36^{*}$ & $-0.56^{* *}$ & -0.20 & -0.33 \\
\hline SLA & $-0.37 *$ & -0.29 & 0.02 & -0.14 & 0.35 * & $-0.55^{* *}$ & $-0.59 * *$ & -0.27 & $-0.40^{* *}$ & $-0.51^{* *}$ & 0.02 & -0.11 & -0.29 & -0.53 ** & -0.16 & -0.29 \\
\hline DES & $-0.33 *$ & $-0.36^{*}$ & 0.08 & $-0.36^{*}$ & $0.44^{* *}$ & $-0.65^{* *}$ & $-0.61^{* *}$ & -0.23 & $-0.61^{* *}$ & $-0.62^{* *}$ & 0.01 & -0.25 & $-0.44^{* *}$ & $-0.62 * *$ & -0.31 & $-0.44^{*}$ \\
\hline IDSE & -0.23 & -0.27 & 0.04 & -0.22 & $0.32 *$ & -0.59 ** & -0.59 ** & -0.25 & $-0.56^{* *}$ & $-0.61^{* *}$ & -0.02 & -0.17 & $-0.37^{*}$ & $-0.65^{* *}$ & -0.14 & -0.27 \\
\hline IDG & 0.01 & -0.20 & -0.02 & -0.33 * & 0.01 & -0.27 & -0.28 & -0.23 & $-0.50^{* *}$ & -0.40 * & 0.08 & -0.21 & -0.25 & -0.30 & -0.27 & -0.35 \\
\hline CEE & -0.23 & $-0.32 *$ & -0.09 & -0.27 & 0.26 & $-0.46^{* *}$ & $-0.42 *$ & -0.14 & $-0.55^{* *}$ & $-0.49^{* *}$ & -0.04 & -0.30 & $-0.35 *$ & $-0.53^{* *}$ & -0.27 & -0.35 \\
\hline TDI & 0.19 & 0.08 & -0.08 & -0.09 & -0.01 & -0.28 & $-0.40 *$ & $-0.47^{* *}$ & -0.30 & -0.25 & -0.16 & -0.22 & -0.23 & -0.28 & 0.03 & -0.08 \\
\hline \%PT & -0.13 & 0.16 & 0.04 & 0.28 & 0.04 & 0.02 & -0.13 & 0.08 & $0.39 *$ & 0.33 & 0.32 & 0.30 & 0.19 & 0.08 & 0.25 & 0.25 \\
\hline LOBO & -0.07 & 0.06 & 0.11 & 0.14 & 0.09 & 0.08 & -0.08 & -0.21 & -0.20 & 0.02 & -0.03 & -0.01 & 0.09 & -0.21 & 0.26 & 0.25 \\
\hline ROTTt & 0.03 & -0.16 & 0.02 & -0.14 & 0.26 & $-0.44^{* *}$ & $-0.45 *$ & -0.38 * & $-0.45^{* *}$ & $-0.45^{*}$ & -0.15 & -0.17 & $-0.39 *$ & $-0.52^{* *}$ & -0.06 & -0.14 \\
\hline ROTTs & -0.13 & -0.17 & 0.04 & -0.19 & 0.22 & $-0.52 * *$ & $-0.54^{* *}$ & -0.33 & $-0.57^{* *}$ & $-0.64^{* *}$ & -0.10 & -0.20 & $-0.40^{*}$ & $-0.59 * *$ & -0.16 & -0.29 \\
\hline WAT & -0.40 * & -0.23 & 0.09 & -0.19 & 0.28 & -0.55 * & -0.58 * & -0.07 & $-0.35 *$ & $-0.60 *$ & 0.22 & 0.01 & -0.18 & $-0.48^{*}$ & -0.15 & -0.30 \\
\hline TIT & -0.24 & -0.08 & 0.10 & -0.01 & -0.01 & 0.30 & 0.32 & 0.15 & 0.31 * & 0.28 & -0.04 & 0.07 & 0.19 & $0.37^{*}$ & -0.13 & -0.03 \\
\hline IDP & -0.15 & $-0.37 *$ & 0.16 & $-0.34^{*}$ & 0.34 * & $-0.52 *$ & $-0.49 *$ & -0.32 & -0.50 * & $-0.57^{*}$ & -0.21 & -0.27 & $-0.51^{*}$ & $-0.49 *$ & $-0.41^{*}$ & -0.51 * \\
\hline $\mathrm{H}^{\prime}$ & -0.18 & 0.03 & 0.10 & -0.21 & 0.11 & $-0.40^{* *}$ & -0.35 & 0.01 & $-0.46^{* *}$ & -0.40 * & 0.30 & -0.15 & -0.15 & -0.32 & -0.12 & -0.24 \\
\hline E & -0.14 & 0.06 & 0.17 & 0.02 & 0.08 & -0.22 & -0.12 & 0.03 & -0.28 & -0.35 & 0.19 & 0.03 & -0.09 & -0.12 & 0.16 & 0.09 \\
\hline $\mathrm{n}$ & 45 & 44 & 44 & 44 & 44 & 43 & 31 & 30 & 44 & 28 & 27 & 41 & 40 & 33 & 29 & 29 \\
\hline
\end{tabular}




\section{Discussion}

The Sakarya River basin is very diverse in terms of land usage and numerous factors e.g., industrial and domestic discharges, and agricultural runoffs may affect the diatom assemblages. In diatom composition of studied waters species form genera Navicula, Nitzschia, Craticula, and Amphora were the most frequent. Most of this species are characterized by occurrence in waters with medium to high trophic level, often saprobity tolerant, up to the $\beta-\alpha$ level [48]. Oligotrophic and mesotrophic species like for example Achnanthidium pyrenaicum [48] were less frequent and occurring mostly in small, undegraded tributaries of the Sakarya River. According to the diatom index values, the lowest values (the worst water quality) were close to big cities (e.g., Ankara) or affected by the presence of extensive agricultural areas in the research area. At these sites, members of the Craticula and Nitzschia genera and Fistulifera saprophila -which are characteristic of strongly polluted, up to polysaprobic, industrial waste waters and heavily degraded environments-were dominated [48]. The water chemistry of the study area show similar regularity of changes as diatom compositions, and was mostly determined by the location of the sampling station in the catchment.

In Turkey, the same analysis of diatom indices and biological water quality assessment were also made in other studies. In a previous study, Solak et al. [31] investigated the source section of river the basin, and the results were similar to the present study: e.g., correlations with the IDAP index and dissolved oxygen or total nitrogen were very similar. However, a comprehensive comparison of the results is impossible due to a small number of analyzed environmental parameters in the cited work. In the present study, most of the evaluated diatom indices were significantly correlated with the important environmental variables at 0.05 and 0.01 importance levels (e.g., biochemical oxygen demand, total nitrogen and phosphate content, phosphates and ammonia ions). Indices such as DES, IDP, and IDAP were correlated with most of the environmental parameters. In contrast, it is reported that the DES index had low correlations with the environmental parameters investigated in the Upper Sakarya Basin [34] and Waal and Vilge Rivers (South Africa) [73].

In a study carried out in the Upper Sakarya Basin [29], Achnanthidium minutissimum showed domination, but was not a dominant diatom species in the present study. In earlier classifications this species was considered as indicator of high ecological studies-for IPS index [21] was highly sensitive. According to [48], this taxon is a ubiquitous species, developing in a wide range of environmental conditions. This is why, as pointed out recent studies [12,18], this species should be excluded from water quality assessments in Europe. This issue likely explains why the earlier studies [29] show mainly good and/or high quality status in the Sakarya River. Contrary to previous studies, the present study indicates much lower water quality around the same bodies of water.

The DES and IDAP indices also reported significantly correlated results with the environmental variables at a high confidence level in the rivers of the subtropical zones of Australia [24]. Both IDAP and DES indices are also recommended for coastal zones [74], which are widely represented around Turkey. The third index considered, which has a number of significant correlations, was the Pampean Diatom Index (IDP). This index was developed in Argentina as a specific biotic index for urban, agricultural and industrial impacted waters [71]. The IDP index was correlated with most of the water parameters examined (at $p$-value 0.05 ). It is important that the IDP index was developed to enable integration of the effect of organic enrichment and eutrophication. The index was improved to distinguish pollution from natural eutrophication phenomena [71]. The Pampean Diatom Index was also successfully applied to other tropical regions. Therefore, it should be noted that the IDP index works both for natural and artificial substratum [75] river basins like the Sakarya, which is anthropogenically transformed and has high naturality. Previous data obtained in Egypt [76] has shown that indices created for similar conditions did not necessarily work in the same specific conditions, while the EPI-D index works very well in Mediterranean rivers [77,78]. One of the most important reasons for limiting the usage of diatom indices adopted from different climate zones (or developed for a specific purpose) is that there are great differences between species structures of diatom assemblages. The important aspect of indices reliability is that the same taxa in various indices have different 
sensibilities on pollution or is not included what causes high variability in the obtained scores [12,21]. In our studies an example are values obtained for DES index, which are much higher than other indices. In this case reasons of the differences in indices values were lack of data (for DES index) for such widespread species as Gomphonema tergestinum and Navicula cryptotenella [21]. In the present study, dominant diatom species occurring in the Sakarya River are also frequent in many European rivers and streams $[13,48,79]$, so important is choosing index comprising ecological data for species from this frequently occurring genera.

The data obtained showed that popular European indices are applicable to Turkish waters. The IPS, IBD, and IDG indices worked with over $90 \%$ of identified taxa in the basin, but IDG, as a generic index, is less precise and showed correlation with only three environmental variables.

In European countries, one of the most popular, and important indices is the IPS-Specific Pollution Sensitivity Index [13,14,80-84]. Blanco et al. [85] compared some biotic indices and diatom indices in the Duero Basin (Spain), and they found that the IPS was the best index to reflect the water quality status of the river. Similarly, significant correlations were reported in other studies elsewhere throughout Europe, such as in French rivers [77], Polish springs and rivers [13,14], Belgian and Luxembourg rivers [86,87], Finnish rivers [53], Hungarian rivers [8,88], Estonian rivers [89], and Portuguese [90]. The Water Framework Directive provides a process to ensure the comparability between the biological monitoring results of Member States and their monitoring system classifications. In order to carry out the intercalibration process EU countries organized Geographical Intercalibration Groups, consisting of Member States sharing particular surface water body types. The important point is that IPS is taking into consideration in formula for intercalibration procedure [91]. In both Mediterranean and Continental ecoregions the IPS index is compulsory in water quality assessment for countries like Belgium, Estonia, Luxemburg, Sweden, Bulgaria, Greece, Portugal, Spain, Cyprus [92]. Turkey, as a country trying to join to the European Union have to take into consideration European law. Two countries-Greece and Bulgaria, with similar climate, which are the closest neighbors of Eastern Turkey (our study area) are also use IPS index. In the present study, the IPS index was significantly correlated with eight environmental variables and the can be applied to Turkish waters.

The TIT (Trophic Index of Turkey) was developed specifically for Turkish rivers [55]. In the present work the TIT index was also calculated, and since there were no significant correlations with environmental parameters and the TIT, it is thought that the index did not work in the watercourses of the Sakarya River basin.

\section{Conclusions}

Because Turkey is a very diverse country in terms of natural environments, to obtain reliable results of diatom indices, the test of a few of them is required. The Tropic Index of Turkey was created especially for monitoring water quality in Turkey but from our studies is possible to draw a conclusion that this index does not work properly in this research area. It seems that European diatom indices (e.g., IPS) may be applicable to studied waters in Turkey.

Supplementary Materials: The following are available online at http://www.mdpi.com/2073-4441/12/3/703/s1, Table S1: List of sampling stations with abbreviations and geographical coordinates.

Author Contributions: C.N.S., Ł.P., É.Á., and G.V. designed the study. H.A.E. and A.M.Y. conducted the field sampling. E.Y. prepared the samples for counting. C.N.S. made qualitative analyses of samples using a light microscope. All authors discussed the results and contributed to the final manuscript. All authors have read and agreed to the published version of the manuscript.

Funding: The project, funded by the General Directorate of State Hydraulic Works in the "DSI Capacity Development, and Water Quality Monitoring Project in Sakarya Basin" during 2017 and 2018 and also the Ministry of Science and Higher Education under the name of "Regional Excellence Initiative" in the years 2019-2022 Project No. 026/RID/2018/19. 
Acknowledgments: The authors wish thank David Duffy for language correction of the manuscript. The authors thank to General Directorate of State Hydraulic Works Investing, Planning and Allocations Department, Environmental Section Managers and Kocaeli University Hydrobiology R\&D Laboratory for their valuable support during the sampling and analysis procedure.

Conflicts of Interest: The authors declare no conflict of interest.

\section{References}

1. Verdonschot, P.F.M. Integrated ecological assessment methods as a basis for sustainable catchment management. Hydrobiologia 2000, 422-423, 389-412. [CrossRef]

2. Kolkwitz, R.; Marsson, M. Grundsätze für die biologische Beurteilung des Wassers nach seiner Flora and Fauna. Mitt. Prüfungsanst. Wasserversorg. Abwasserreinig 1902, 1, 33-72.

3. Kolkwitz, R.; Marsson, M. Ökologie der tierischen saprobien. Beiträge zur lehre von biologischen Gewasserbeurteilung. Int. Revue Gesamten Hydrobiol. Hydrogr. 1909, 2, 126-152. [CrossRef]

4. Cholnoky, B.J. Die Ökologie der Diatomeen in Binnengewässern; Cramer, J., Ed.; J. Cramer: Lehre, Germany, 1968; pp. 1-699.

5. Patrick, R. Ecology of freshwater diatoms and diatom communities. In The Biology of Diatoms; Werner, D., Ed.; Blackwell: Oxford, UK, 1977; pp. 284-332.

6. Directive, W.F. Directive 2000/60/EC of the European Parliament and of the Council of 23 October 2000 establishing a framework for Community action in the field of water policy. Off. J. Eur. Commun. 2000, 22, 2000.

7. Smol, J.P.; Stoermer, E.F. The Diatoms: Applications for the Environment and Earth Sciences; Cambridge University Press: New York, NY, USA, 2010; pp. 570-573.

8. Ács, É.; Szabó, K.; Tóth, B.; Kiss, K.T. Investigation of benthic algal communities, especially diatoms of some Hungarian streams in connection with reference conditions of the water framework directives. Acta Bot. Hung. 2004, 46, 255-277. [CrossRef]

9. Stevenson, R.J.; Bothwell, M.L.; Lowe, R.L. Algal Ecology: Freshwater Benthic Ecosystems; Academic Press: San Diego, CA, USA, 1996.

10. Tapolczai, K.; Bouchez, A.; Stenger-Kovács, C.; Padisák, J.; Rimet, F. Trait-based ecological classifications for benthic algae: Review and perspectives. Hydrobiologia 2016, 776, 1-17. [CrossRef]

11. Xeu, H.; Zheng, B.; Meng, F.; Wang, Y.; Zhang, L.; Cheng, P. Assessment of aquatic ecosystem health of the Wutong River based on benthic diatoms. Water 2018, 11, 1-17.

12. Besse-Lototskaya, A.; Verdonschot, P.F.M.; Coste, M.; van de Vijver, B. Evaluation of European diatom trophic indices. Ecol. Indic. 2011, 11, 456-467. [CrossRef]

13. Noga, T.; Stanek-Tarkowska, J.; Peszek, Ł.; Pajączek, A.; Kochman-Kędziora, N.; Ligęzka, R. The use of diatoms to assess the water quality in the Wisłoka River in the town of Debica and the surrounding area. Oceanol. Hydrobiol. Stud. 2016, 45, 191-201. [CrossRef]

14. Kwandrans, J.; Eloranta, P.; Kawecka, B.; Wojtan, K. Use of benthic diatom communities to evaluate water quality in rivers of southern Poland. J Appl. Phycol. 1998, 10, 193-201. [CrossRef]

15. Dell'Uomo, A. Assessment of water quality of an Apennine river as a pilot study for diatom-based monitoring of Italian watercourses. In The Use of Algae for Monitoring Rivers II.; Whitton, B.A., Rott, E., Eds.; Institut für Botanik Universität Innsbruck: Innsbruck, Austria, 1996; pp. 65-72.

16. Kelly, M.G.; Whitton, B.A. The trophic diatom index: A new index for monitoring eutrophication in rivers. J. Appl. Phycol. 1995, 7, 433-444. [CrossRef]

17. Kelly, M.G.; Chiriac, G.; Soare-Minea, A.; Hamchevici, C.; Birk, S. Defining ecological status of phytobenthos in very large rivers: A case study in practical implementation of the Water Framework Directive in Romania. Hydrobiologia 2018, 828, 353-367. [CrossRef]

18. Szczepocka, E.; Żelezna-Wieczorek, J.; Nowicka-Krawczyk, P. Critical approachto diatom-based bioassessment of the regulated sections of urban flowing water ecosystems. Ecol. Indic. 2019, 104, 259-267. [CrossRef]

19. Ponader, K.C.; Charles, D.F.; Belton, T.J. Diatom-based TP and TN inference models and indices for monitoring nutrient enrichment of New Jersey streams. Ecol. Indic. 2007, 7, 79-93. [CrossRef] 
20. Potapova, M.; Charles, D.F. Diatom metrics for monitoring eutrophication in rivers of the United States. Ecol. Indic. 2007, 7, 48-70. [CrossRef]

21. Lecointe, C.; Coste, M.; Prygiel, J. “Omnidia”: Software for taxonomy. Calculation of diatom indices and inventories management. Hydrobiologia 1993, 269-270, 509-513. [CrossRef]

22. Zgrundo, A.; Peszek, Ł.; Poradowska, A. Podręcznik do Monitoringu i Oceny Rzecznych Jednolitych Części wód Powierzchniowych na Podstawie Fitobentosu; Główny Inspektorat Ochrony Środowiska: Gdańsk, Poland, 2018; pp. 1-70.

23. Pipp, E. A regional diatom-based trophic state indication system for running water sites in Upper Austria and its overregional applicability. Verh. Int. Verein. Limnol. 2002, 27, 3376-3380. [CrossRef]

24. Tan, X.; Zhang, Q.; Burford, M.A.; Sheldon, F.; Bunn, S.E. Benthic diatom based indices for water quality assessment in two subtropical streams. Front. Microbiol. 2017, 8, 601. [CrossRef] [PubMed]

25. Tierno de Figueroa, J.M.; Lopez-Rodriguez, M.J.; Fenoglio, S.; Sanchez-Castillo, P.; Fochetti, R. Freshwater biodiversityin the rivers of the Mediterranean Basin. Hydrobiologia 2013, 719, 137-186. [CrossRef]

26. Giorgio, A.; Bonis, S.; Guida, M. Macroinvertebrate and diatom communities as indicators for the biological assessment of river Picentino (Campania, Italy). Ecol. Indic. 2016, 64, 85-91. [CrossRef]

27. Brabcová, B.; Marvan, P.; Opatřilová, L.; Brabec, K.; Fránková, M.; Heteŝa, J. Diatoms in water quality assessment: To count or not to count them? Hydrobiologia 2017, 795, 113-127. [CrossRef]

28. Pardoa, I.; Delgadoa, C.; Abraína, R.; Gómez-Rodríguezb, C.; García-Rosellóc, E.; Garcíaa, L.; Reynoldsond, T.B. A predictive diatom-based model to assess the ecological status of streams and rivers of Northern Spain. Ecol. Indic. 2018, 90, 519-528. [CrossRef]

29. Çetin, T.; Demir, N. The use of phytobenthos for the ecological status assessment in Upper Sakarya Basin. Turkey. Appl. Ecol. Env. Res. 2017, 17, 10155-10172.

30. Karaouzas, I.; Smeti, E.; Kalogianni, E.; Skoulikidis, N.T. Ecological status monitoring and assessment in Greek rivers: Do macroinvertebrate and diatom indices indicate same responses to anthropogenic pressures? Ecol. Indic. 2019, 101, 126-132. [CrossRef]

31. Solak, C.N.; Ector, L.; Wojtal, A.Z.; Ács, É.; Morales, E.A. A review of investigations on diatoms (Bacillariophyta) in Turkish inland waters. Nova Hedwig. Beih. 2012, 141, 431-462.

32. Atıc1, T.; Yıldız, K. Sakarya Nehri Diyatomları. Turk. J. Bot. 1996, 20, 119-134.

33. Yıldız, K. Diatoms of the Porsuk River, Turkey. Doğa Tr. J. Biol. 1987, 11, 162-182.

34. Atıc1, T.; Ahıska, S. Pollution and algae of Ankara stream. Gazi Univ. J Sci. 2005, 18, 51-59.

35. Tokatlı, C. Sucul sistemlerin izlenmesinde bazı diyatome indekslerinin kullanılması: Gürleyik Çayı örneği (Eskişehir). Dumlupınar Üniversitesi Bilimleri Enstitüsü Dergisi 2012, 29, $19-26$.

36. Yaykiran, S. Structuring the High Resolution Hydrological Model of Sakarya Basin; MSc-Istanbul Technical University, Institute of Science and Technology: İstanbul, Turkey, 2016; pp. 1-204.

37. Günay, G. Hydrology and hydrogeology of Sakaryabaşı Karstic springs, Çifteler, Turkey. Environ. Geol. 2006, 51, 229-240. [CrossRef]

38. Japan Society of Civil Engineers, Earthquake Engineering Committee. The 1999 Kocaeli Earthquake, Turkey_Investigation into Damage to Civil Engineering Structures. 1999. Available online: http://www. jsce.or.jp/library/eq_repo/Vol1/TURKEY/kocaeli_E.html (accessed on 15 October 2019).

39. Krammer, K.; Lange-Bertalot, H. Bacillariophyceae. 1. Teil: Naviculaceae. Süßwasserflora Mitteleur. 1986, 2, 1-876.

40. Krammer, K.; Lange-Bertalot, H. Bacillariophyceae. 2. Teil: Bacillariaceae. Epithemiaceae. Surirellaceae. Süßwasserflora Mitteleur. 1988, 2, 1-596.

41. Krammer, K.; Lange-Bertalot, H. Bacillariophyceae. 3. Teil: Centrales. Fragilariaceae Eunotiaceae. Süßwasserflora Mitteleur. 1991, 2, 1-576.

42. Krammer, K.; Lange-Bertalot, H. Bacillariophyceae. 4. Teil: Achnanthaceae. Kritische Erganzungen zu Navicula (Lineolatae) und Gomphonema. Gesamtliteraturverzeichnis. Süßwasserflora Mitteleur. 1991, 2, 1-437.

43. Reichardt, E. Zur Revision der Gattung Gomphonema. Die Arten um G. affine/insigne.G. angustatum/micropus. G. acuminatum sowie gomphonemoide Diatomeen aus dem Oberoligozän in Böhmen. Iconogr. Diatomol. 1999, 8, 1-203.

44. Krammer, K. Pinnularia. Diatoms of the European Inland Waters and Comparable Habitats. Diatoms Eur. 2000, 1, 1-703. 
45. Krammer, K. Cymbella. Diatoms of the European Inland Waters and Comparable Habitats. Diatoms Eur. 2002, 3, 1-584.

46. Lange-Bertalot, H. Navicula sensu stricto. 10 Genera separated from Navicula sensu lato. Frustulia. Diatoms of the European inland waters and comparable habitats. Diatoms Eur. 2001, 2, 1-526.

47. Lange-Bertalot, H.; Cavacini, P.; Tagliaventi, N.; Alfinito, S. Diatoms of Sardinia. Rare and 76 new species in rock pools and other ephemeral waters. Iconogr. Diatomol. 2003, 12, 1-438.

48. Lange-Bertalot, H.; Hofmann, G.; Werum, M.; Cantonati, M. Freshwater Benthic Diatoms of Central Europe: Over 800 Common Species Used in Ecological Assessment, English Edition with Updated Taxonomy and Added Species; Koeltz Botanical Books: Schmitten-Oberreifenberg, Germany, 2017; pp. 1-942.

49. Werum, M.; Lange-Bertalot, H. Diatoms in springs from Central Europe and elsewhere under the influence of hydrologeology and anthropogenic impacts. Iconogr. Diatomol. 2004, 13, 1-417.

50. Houk, V.; Klee, R.; Tanaka, H. Atlas of freshwater centric diatoms with a brief key and descriptions. Part III. Stephanodiscaceae A: Cyclotella. Tertiarius. Discostella. Fottea 2010, 10, 1-498.

51. Levkov, Z.; Metzeltin, D.; Pavlov, A. "Luticola and Luticopsis". Diatoms of the European Inland Waters and Comparable Habitats. Diatoms Eur. 2013, 7, 1-697.

52. Wojtal, A.Z. Species composition and distribution of diatom assemblages in spring waters from various geological formations in Southern Poland. Bibl. Diatomol. 2013, 59, 1-436.

53. Eloranta, P.; Soininen, J. Ecological status of some finish rivers evaluated using benthic diatom communities. J. Appl. Phycol. 2002, 14,1-7. [CrossRef]

54. Dumnicka, E.; Jelonek, M.; Klich, M.; Kwandrans, J.; Wojtal, A.; Żurek, R. Ichtiofauna i Status Ekologiczny wód Wisty, Raby, Dunajca i Wistoki; Institute of Nature Conservation, Polish Academy of Science: Kraków, Poland, 2006; pp. 164-166.

55. Çelekli, A.; Toudjani, A.A.; Gümüş, E.Y.; Kayhan, S.; Lekesiz, H.Ö.; Çetin, T. Determination of trophic weight and indicator values of diatoms in Turkish running waters for water quality assessment. Turk. J. Bot. 2019, 43, 90-101. [CrossRef]

56. Prygiel, J.; Coste, M. Recent trends in monitoring French rivers using algae, especially diatoms. In Use of Algae for Monitoring Rivers II; Whitton, B.A., Rott, E., Eds.; Institut für Botanik. Universität Innsbruck: Schmitten, Austria, 1996; pp. 87-96.

57. Lenoir, A.; Coste, M. Development of a practical diatom index of overall water quality applicable to the French National Water Board network. In The Use of Algae for Monitoring Rivers II.; Whitton, B.A., Rott, E., Eds.; Institut für Botanik Universität Innsbruck: Schmitten, Austria, 1996; pp. 29-43.

58. Steinberg, C.; Schiefele, S. Biological Indication of Trophy and Pollution of Running Waters. Z. Wasser Abwasser-Forsch. 1988, 21, 227-234.

59. Schiefele, S.; Schreiner, C. Use of diatoms for monitoring nutrient enrichment acidification and impact salts in Germany and Austria. In Use of Algae for Monitoring Rivers; Whitton, B.A., Rott, E., Friedrich, G., Eds.; Institut für Botanik Universität Innsbruck: Schmitten, Austria, 1999; pp. 1-193.

60. Hürlimann, J.; Niederhauser, P. Méthode d'Analyse et d'Appréciation des Cours d'eau en Suisse, Diatomées, Niveau $R$ Région; Office Fédéral de l'Environnement, des Forêts et du Paysage OFEFP: Berne, Switzerland, 2002; pp. 1-111.

61. CEMAGREF. Etude des Méthods Biologiques Quantatatives d'Appréciation de la Qualité des Eaux. Rapport Division Qualité des Eaux Lyon; Agence Financiére de Bassin Rhône, Mediterranée-Corse: Lyon, French, 1982; pp. 1-218.

62. Sládeček, V. Diatoms as indicators of organic pollution. Acta Hydrochim. Hydrobiol. 1986, 14, 555-566. [CrossRef]

63. Descy, J.P. A new approach to water quality estimation using diatoms. Nova Hedwig. 1979, 64, 305-323.

64. Leclerq, L.; Maquet, B. Deux nouveaux índices chimique et diatomique de qualité d'eau courante: Comparaison avec diérents indices existants. Cah. Biol. Mar. 1987, 28, 303-310.

65. Coste, M.; Ayphassorho, H. Etude de la qualité des eaux du Bassin Artois-Piccardie á l' aide des communautés des diatomées benthiques (application des indices diatomiques). In Rapport CEMAGREF, Bordeaux; Agence de l'Eau Artois-Picardie: Douai, France, 1991; pp. 1-227.

66. Descy, J.P.; Coste, M. A test of methods for assessing water quality based on diatoms. Verh. Intern. Limnol. 1991, 24, 2112-2216. [CrossRef] 
67. Lobo, E.A.; Callegaro, V.L.M.; Hermany, G.; Bes, D.; Wetzel, C.A.; Oliveira, M.A. Use of epilithic diatoms as bioindicator from lotic systems in southern Brazil, with special emphasis on eutrophication. Acta Limnol. Bras. 2004, 16, 25-40.

68. Rott, E.; Hofmann, G.; Pall, K.; Pfister, P.; Pipp, E. Indikationslisten für Aufwuchsalgen in Österreichischen Fliessgewässern, Teil 1: Saprobielle Indikation Wasserwirtschaftskataster; Bundeministerium für Land- und Forstwirtschaft: Wienna, Astralia, 1997; pp. 1-73.

69. Rott, E.; Pfister, P.; Van Dam, H.; Pipp, E.; Pall, K.; Binder, N.; Ortler, K. Indikationslisten für Aufwuchsalgen; Bundesministerium für Land-und Forstwirtschaft: Wienna, Astralia, 1999; pp. 1-248.

70. Watanabe, T.; Asai, K.; Houki, A. Numerical water quality monitoring of organic pollution using diatom assemblages. Sci. Total Environ. 1986, 55, 209-218. [CrossRef]

71. Gomez, N.; Licursi, M. The Pampean Diatom Index (IDP) for assessment of rivers and streams in Argentina. Aquat. Ecol. 2001, 35, 173-181. [CrossRef]

72. American Public Health Association. Standard Methods for the Examination of Water and Wastewater, 22nd ed.; Rice, E.W., Baird, R.B., Eaton, A.D., Eds.; Clesceri. American Public Health Association (APHA): Washington, DC, USA; American Water Works Association (AWWA): Denver, CO, USA; Water Environment Federation (WEF): Cologny, Switzerland, 2012; pp. 1-541.

73. Taylor, J.C.; Janse van Vuuren, M.S.; Pieterse, A.J.H. The application and testing of diatom-based indices in the Vaal and Wilge Rivers. South Africa. Water SA 2007, 33, 51-60. [CrossRef]

74. Zgrundo, A.; Bogaczewicz-Adamczak, B. Applicability of diatom indices for monitoring water quality in coastal streams in the Gulf of Gdansk Region. Northern Poland. Oceanol. Hydrobiol. Stud. 2004, 33, 31-46.

75. Bere, T.; Tundisi, J.G. Applicability of the Pampean Diatom Index (PDI) to streams around São Carlos-SP. Brazil. Ecol. Indic. 2012, 13, 342-346. [CrossRef]

76. El-Karim, M.S.A. Epipelic algal distribution in Ismailia Canal and the possible use of diatoms as bioindicators and a biomonitoring tool. Egypt. J. Aquat. Res. 2014, 40, 385-393. [CrossRef]

77. Dell'Uomo, A.; Pensieri, A.; Corradetti, D. Diatomees epilithiques du fleuve Esino (Italia centrale) et leur utilisation pour l'evaluation de la qualite biologique de l'eau. Cryptogam. Algol. 1999, 20, 253-269. [CrossRef]

78. Torrisi, M.; Dell'Uomo, A. Biological monitoring of some Apennine rivers (Central Italy) using the diatom-based Eutrophication/Pollution Index (EPI-D) compared to other European diatom indices. Diatom Res. 2006, 21, 159-174. [CrossRef]

79. Noga, T.; Kochman, N.; Peszek, Ł.; Stanek-Tarkowska, J.; Pajączek, A. Diatoms (Bacillariophyceae) in rivers and streams and on cultivated soils of the Podkarpacie region in the years 2007-2011. Ecol. Eng. 2014, 15, 6-25.

80. Martín, G.; Fernández, R.M. Diatoms as Indicators of Water Quality and Ecological Status: Sampling, Analysis and Some Ecological Remarks. In Ecological Water Quality-Water Treatment and Reuse; Vaudouris, K., Ed.; InTech: Rijeka, Croatia, 2012; pp. 183-204.

81. Ector, L.; Wetzel, C.E.; Novais, M.H.; Guillard, D. Atlas des Diatomées des Rivières des Pays de la Loire et de la Bretagne; DREAL Pays de la Loire: Nantes, French, 2015; pp. 1-649.

82. Kelly, M.; Bennion, H.; Burgess, A.; Ellis, J.; Juggins, S.; Guthrie, R.; Jamieson, J.; Adriaenssens, V.; Yallop, M. Uncertainty in ecological status assessments of lakes and rivers using diatoms. Hydrobiologia 2009, 633, 5-15. [CrossRef]

83. Kelly, M.; Bennett, C.; Coste, M.; Delgado, C.; Delmas, F.; Denys, L.; Ector, L.; Fauville, C.; Ferréol, M.; Golub, M.; et al. A comparison of national approaches to setting ecological status boundaries in phytobenthos assessment for the European Water Framework Directive: Results of an intercalibration exercise. Hydrobiologia 2009, 621, 169-182. [CrossRef]

84. Solak, C.N.; Ács, É. Water quality monitorıng in European and Turkısh rivers using diatoms. Turk. J. Fish. Aquat. Sc. 2011, 11, 329-337.

85. Blanco, S.; Becares, E.; Cauchie, H.-M.; Hoffmann, L.; Ector, L. Comparison of biotic indices for water quality diagnosis in the Duero Basin (Spain). Arch. Hydrobiol. Suppl. 2007, 161, 267-286. [CrossRef]

86. Descy, J.P.; Ector, L. Use of diatoms for monitoring rivers in Belgium and Luxemburg. In Use of Algae for Monitoring Rivers III; Prygiel, J., Whitton, B.A., Bukowska, J., Eds.; Agaence de l'Eau Artois-Picardie: Douai, French, 1999; pp. 128-137.

87. Rimet, F.; Ector, L.; Cauchi, H.M.; Hoffmann, L. Regional distribution of diatom assemblages in the headwater streams of Luxembourg. Hydrobiologia 2004, 520, 105-117. [CrossRef] 
88. Ács, É.; Borics, G.; Fehér, G.; Kiss, K.T.; Reskóne, N.M.; Stenger-Kovács, C.S.; Vábríró, G. Implementation of the European Water Framework Directive to assessment the water quality of Hungarian running waters with diatoms. Diatomededelingen 2009, 33, 29-33.

89. Vilbaste, S.; Truu, J.; Leisk, U.; Iital, A. Species composition and diatom indices in relation to environmental parameters in Estonian streams. Arch. Hydrobiol. Suppl. 2007, 17, 307-326. [CrossRef]

90. Almeida, S.F.P. Use of diatoms for freshwater quality evaluation in Portugal. Limnetica 2001, 20, $205-213$.

91. Commission Decision (EU) 2018/229 of 12 February 2018, Establishing, Pursuant to Directive 2000/60/EC of the European Parliament and of the Council, the Values of the Member State Monitoring System Classifications as a Result of the Intercalibration Exercise and Repealing Commission Decision 2013/480/EU. Available online: https://eur-lex.europa.eu/legal-content/EN/TXT/?uri=CELEX\%3A32018D0229 (accessed on 17 January 2020).

92. Commission Decision (EU) 2005/646/EC of 17 August 2005 on the Establishment of a Register of Sites to Form the Intercalibration Network in Accordance with Directive 2000/60/EC of the European Parliament and of the Council. Available online: https://eur-lex.europa.eu/legal-content/GA/TXT/?uri=CELEX:32013D0480 (accessed on 17 January 2020).

(C) 2020 by the authors. Licensee MDPI, Basel, Switzerland. This article is an open access article distributed under the terms and conditions of the Creative Commons Attribution (CC BY) license (http://creativecommons.org/licenses/by/4.0/). 